\title{
GERAÇÃO E DIFUSÃO DE INOVAC,ÕES TECNOLOGICAS NA AGRICULTURA BRASILEIRA: O CASO DO MILHO PIRANÃO
}

\author{
NICOLAU MIGUEL SCHAUN \\ ENGENHEIRO AGRONNOMO
}

Orientador: Prof. Dr. JOSE MOLINA FILHO

\begin{abstract}
Dissertação apresentada à Escola Superior de Agricultura "Luiz de Queiroz", da Universidade de São Paulo, para obtenção do titulo de Mestre em Agronomia. Área de concentração: Sociologia Rural.
\end{abstract}

P I R A C I C A B A

Estado de São Paulo - Brasil

Junho, 1984 
A Eliana, companheira e "musa inspiradora" como mulher solidäria na dimensão plena da perspectiva libertäria. A Mārcia e Marina, produtos genéticos de um lado e sujeitos e objetivos de uma sociedade que se pretende mais humana e solidaria de outro e para o que se deve trabalhar. 


\section{AGRADECIMENTOS}

A Empresa Brasileira de Pesquisa Agropecuāria, onde trabalho, pela oportunidade oferecida para a realização do curso.

Aos colegas Pesquisadores do Centro Nacional de Pesquisa de Milho e Sorgo, que constituiram, pelas expectativas, sempre manifestas, o maior estímulo a que pensāssemos em Difusão de Tecnologia como coisa realmente séria e a que, portanto deveríamos dar uma dimensão verdadeiramente científica.

Ao Professor José Molina Filho a partir de cuja crítica sempre frequente e orientação cuidadosa, forjou-se uma amizade indelével.

Aos Professores Manoel Antônio de Almeida Monteiro e José Roberto Medina Landim, do Departamento de Economia Rural da Faculdade de Ciências Agrärias e Veterinārias de Jaboticabal - UNESP, companhei ros a um tempo incansáveis e tolerantes pelas contribuições indispensáveis a que se pudesse legar um documento no mínimo necessário à "Difusão de Tecnologia dentro da Pesquisa".

Aos Professores e Funcionärios do Departamento de Economia e Sociologia Rural da Escola Superior de Aaricultura Luiz de Queiroz pela dedicação e sensibilidade com que nos proporcionaram a incorporação de conhecimentos indiscuti- 
velmente importantes e necessärios ao nosso labor profissional.

Aos colegas Ricardo Magnavaca e Francisco Geraldo França Teixeira de Castro Bahia então respectivamente Chefe e Chefe Adjunto Técnico do Centro Nacional de Pesquisa de Milho e Sorgo que, numa demonstração inequívoca de profunda acuidade para as perspectivas da EMBRAPA e de rara sensibilidade para o fato de que a matéria prima das ações do trabalhador, em Difusão de Tecnologia é o homem na sua plena dimensão assumiram a atitude obstinada mesmo de valorizar, apoiar e estimular os estudos do autor na ärea de Sociologia Rural.

Aos colegas de trabalho Juvenal de Souza Ramos e Maria Elizabeth Horta Avelar pelos primorosos trabalhos de revisão e datilografia deste estudo.

Finalmente sou grato a todas as pessoas que, direta ou indiretamente, contribuiram para a viabilização deste trabalho. 


\section{CURRICULUM VITAE}

NICOLAU MIGUEL SCHAUN, filho de Nelson Schaun e de Vanja Miguel Schaun, nasceu na cidade de Ilhéus, Estado da Bahia, a 02 de outubro de 1940 .

Formado Engenheiro Agrónomo em 15 de dezembro de 1968 pela Escola Agronômica da Universidade Federal da Bahia, Cruz das Almas, Bahia.

Trabalhou na CEPLAC (Comissão Executiva do Plano da Lavoura Cacaueira), como Extensionista, no período de maio de 1970 a janeiro de 1975. Durante o ano de 1975 experimentou, como autónomo, a atividade de administração Rural com a responsabilidade técnica de dar continuidade ao maior projeto em implantação na época, de cacaueiros híbridos em onze unidades produtivas de Nestor Mesquita Martins, Ipiau, Bahia.

Em 1976, iniciou suas atividades como Pesquisador da EMBRAPA, desenvolvendo, no Centro Nacional de Pesquisa de Milho e Sorgo, o programa de Difusão de Tecnologia. Em 1978 iniciou o Curso de Pós graduação em Sociologia Rural no Departamento de Economia e Sociologia Rural da ESALQ/USP, tendo concluido a obtenção dos crëditos em 1979. 


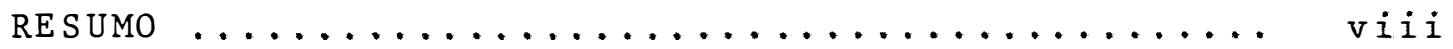

SUMMARY $\ldots \ldots \ldots \ldots \ldots \ldots \ldots \ldots \ldots \ldots \ldots \ldots \ldots \ldots \ldots \ldots \ldots \ldots$

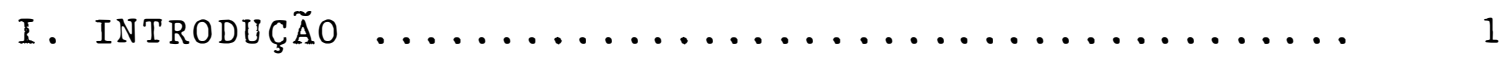

1. Importância e objetivos ................. I

2. O Milho Piranão Como Uma Inovação Tecnologica.. 12

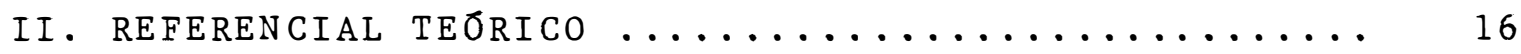

1. Aspectos Históricos da Pesquisa Agrícola no Bra

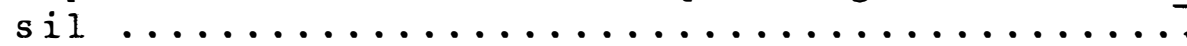

2. A Perspectiva Interdisciplinar no Processo da

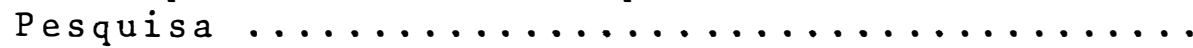

3. Difusão de Tecnologia ................. 45

III . METODOLOGIA $\ldots \ldots \ldots \ldots \ldots \ldots \ldots \ldots \ldots \ldots \ldots \ldots \ldots \ldots \ldots \ldots \ldots$

1. Area do Estudo ...................... 57

2. Critérios de Amostragem .................. 59

3. Obtenção dos Dados ..................... 64

4. Informações Adicional Sobre os Municípios Estu-

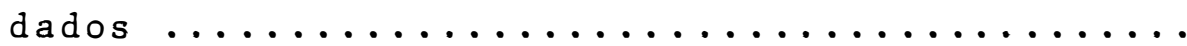

IV. Análise E discuss $\widetilde{O}$ dos Resultados $\ldots \ldots \ldots \ldots \ldots \ldots 77$

1. Critérios de Tecnologia Etil Alocados Pelos Pesquisadores que Trabalharam na Geração do Milho

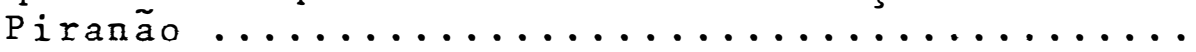

2. A Expectativa de Atitudes dos Produtores em Fa-

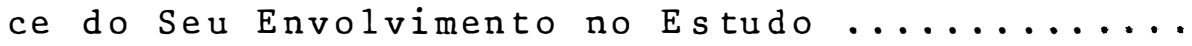

3. Reações dos Produtores em Relação às suas observações Feitas em Campo, Sobre o Milho Pira-

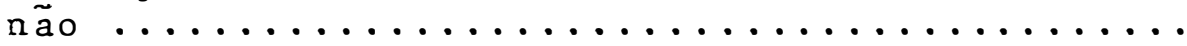


. vii.

Págin a

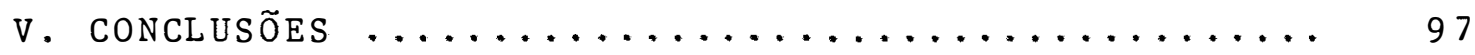

VI. BIBLIOGRAFIA $\ldots \ldots \ldots \ldots \ldots \ldots \ldots \ldots \ldots \ldots \ldots \ldots \ldots \ldots \ldots \ldots \ldots$

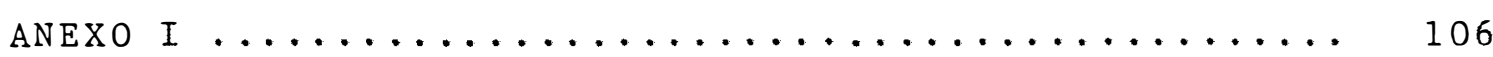

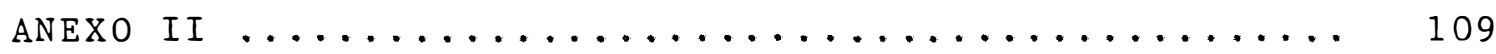

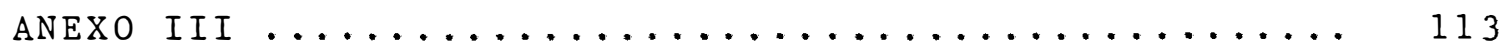

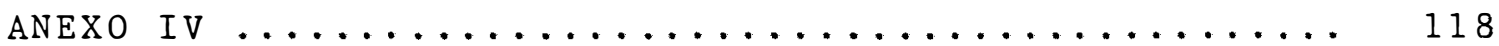


. viii.

\section{GERAÇÃO E DIFUSÃO DE INOVAÇÕES TECNOLŌGICAS NA AGRICULTURA BRASILEIRA: O CASO DO MILHO PIRANÃO}

Nicolau Miguel Schaun

Prof. Dr. José Molina Filho

- ORIENTADOR -

RESUMO

objetiva o presente estudo, identificar os fatores componentes do processo de geração do milho piranão, e que possam estar vinculados à sua não adoção e utilização peprodutores.

Para tanto, partiu-se do esforço de estabelecer as características diferenciais mais marcantes entre o conceito clāssico de "Difusão de Tecnologia" e o que se pretende na EMBRAPA - Empresa Brasileira de Pesquisa Agropecuāria, dentro do seu modelo e dos seus objetivos operacionais, alcançar em termos desse mesmo conceito de Difusão de Tecnologia.

Utilizou-se o "Mi tho "piranão", caracterizado como uma inovação tecnolögica, "gerada pelo Departamento de Genëtica da Escola Superior de Agricultura Luiz de Queiroz", Piracicaba e, partindo-se do fato de que ele não tem sido utilizado em larga escala pelos produtores de mi iho no Bra- 
sil, buscou-se estudar os critērios de sua geração adotados pelos pesquisadores nela envolvidos.

Para nortear teóricamente o presente estudo, partiu-se do conceito de interdisciplinaridade, perspectiva metodológica que busca identificar as conexões intra e intersistemas o que constitui, hoje, o objetivo operacional do modelo de pesquisa e Geração de Tecnologia da EMBRAPA.

Os dados obtidos para confirmar empiricamente este estudo resultaram da seguinte metodologia operacional adotada: Distribuiu-se a um nümero significativo de Produtores de milho (151) da Microregião Homogênica Serra de Jaboticabal, São Paulo, $1 \mathrm{Kg}$ de Sementes de Milho Piranäo a cada um dos Produtores Selecionados. Após o seu plantio, ao lado do mi lho tradicionalmente cultivado na Região, buscou-se identificar junto aos produtores, as observações comparativas feitas por eles, a partir do que, esperava-se uma atitude de adoção ou rejeição por parte dos produtores. Com base nesse referencial, chegou-se à verificação de que a adoção do Milho Pi ranão na região onde ele foi estudado não alcançou resultados desejáveis e um dos fatores que contribuiu significativamente para a-sua não adoção em larga escala está vinculado à sua geração, principalmente na etapa de identificação do problema de pesquisa, etapa em que o conhecimento da realidade de fato pelo Pesquisador é fundamental para nortear a definição e seleção do problema de pesquisa 
"A dissociação sempre crescente das disciplinas cientificas, segundo um processo de inflação galopante, constitui a expressão de um desmembramento da realidade humana. A "tünica inconsūtil" da unidade do saber dissociou-se em parcelas cada vez mais diminutas. A ciência em migalhas de nossa ëpoca não passa de reflexo de uma consciência esmigalhada, incapaz de formar uma imagem de conjunto do mundo atual. Donde o desequilíbrio ontológico de que padece nossa civilização". 
.$x i$.

GERAÇÃO E DIFUSÃo DE INOVAÇÕES TECNOLÕgICAS NA AGRICULTURA BRASILEIRA: O CASO DO MILHO PIRANÃO

Nicolau Miguel Schaun

Prof. Dr. José Molina Filho

- ORIENTADOR -

SUMMRY

The purpose of the present study is to identify the component factors in the generation process of a new corn cultivar "Piranão", and those related to the feasiability of its adoption or not and its utilization by the farmers.

For this purpose it was started from the effort to stabilish the more remarkable differential characteristics between the classic concept of Technology Diffusion and what is intended by EMBRAPA, "Empresa Brasileira de Pesquisa Agropecuārial", whitin its model and their operational goals.

The corn cultivar "Piranão" was utilized in this study as the innovation technology. It was created by the Genetic's in the Department in the "Escola Superior de Agricultura Luiz de Queiroz", Piracicaba, Brasil. It was assumed that the "Piranão" cultivar has not been utilized in a large scale by the Brazilian corn growers Thus it was Searched to study the cultivar generation criteria adopted by the researshers involved 
in that process.

In order to direct the present study by the theorectical fundamentals it was started with the concept of interdisciplinarity. This methodologic perspective try to identify the connections "intra" and "inter" systems, shat constitute, today, the operational goal in the generation technology model in EMBRAPA research.

To empirically comfirm this study the gathered data was resulted from the following adapted operational methodology: It was distributed one Kilograme of "piranão" corn seed to each of 151 corn growers in the hommogeneous microregion of "Serra de Jaboticabal", São Paulo, Brasil. After the planting time, besides the tradition ally corn cultivar growing in the region, it was searched to identify the growers comparative observations, from which it was expected the technology adoption or rejection by them. Based in that referential it was verified that the adoption of the new corn cultivar in the cited microregion of study did not reached the disirable results. One of the factors which substantially contributed to the no adoption of the new technology in a large scale was related to its generation process. 
GERAÇÃO E DIFUSÃO DE INOVAÇÖES TECNOLOGICAS NA AGRICULTURA BRASILEIRA: 0 CASO DO MILHO PIRANAO

1. INTRODUÇAO

1. Importância e objetivos

Um dos problemas que se tem identificado com bastante frequência na EMBRAPA (Empresa Brasileira de Pesquisa Agropecuäria) em relação à Difusão de Tecnologia é a clara compreensão do próprio conceito de "Difusão de Tecnologia".

Provavelmente, um dos fatores que mais tem contribuído para o aguçamento desse fato é que "Difusão de Tecnologia" tem sido considerado um processo que se inicia a partir da tecnologia jä existente por haver sido ela criada ou mesmo descoberta, e que precisa ser introduzida num determido Sistema Social. Segundo Frank (1975), ao discutir a abordagem difusionista como uma perspectiva de desenvolvimento e mudança social, elaborada por Hanning Hash - e a adoção e uti- 
lização de inovações tecnolögicas constitui uma forma de mudança social - considera que o desenvolvimento "ocorre" através da difusão de elementos culturais dos países desenvolvidos para os subdesenvolvidos. Isto implica, naturalmente, a aculturação desses elementos por parte dos países subdesenvolvidos. Observa-se que a difusão expande-se das metrópoles dos países desenvolvidos avançados para as capitais nacionais dos subdesenvolvidos e destas, por sua vez, para as capitais do interior e, finalmente, para as regiões periféricas do interior. Segundo esse ponto de vista, o desenvolvimento é promovido pela difusão e pela aculturação. o subdesenvolvimento permanece devido aos obstáculos ou à resistência à dífusão e é tomado como estado "tradicional" original. "... De fato, ainda afirma Frank (1975), "os difusores não sugerem aos povos do mundo subdesenvolvido, que investiguem e eliminem as causas do subdesenvolvimento; aos invés disso, aconselham aguardar e acolher a difusão da ajuda desenvolvimentista do exterior". Mais que isso, alēm da consideração de que a difusão poderia vir do exterior, (tecnologia importada) ao longo do tempo, a continuidade de um processo com essas características, juntamente com o fato de que parte dos pesquisadores têm a sua formação no exterior, o referencial dos pesquisadores, por vezes, é externo, desconsiderando portanto as verdadeiras e reais características da agricultura nacional.

No presente estudo, então, vamos estabelecer o raciocínio da seguinte forma: Existem "inovações" que são as 
tecnologias para a Cultura do Milho (Zea mayz, L.). Essas tecnologias precisam, portanto, ser introduzidas num determinado sistema social formado pelos produtores de milho. Para isso, então, necessita-se lançar mão da ação de profissíonais, no caso Extensionistas, que, munidos de um conjunto de mecanismos de comunicação e persuasão, devem realizar essa tarefa de persuadir e induzir os produtores a adotarem tais tecnologias.

Esse processo de transferência de tecnologia aos produtores rurais, também conhecido como "Difusão de Tecnologia" tem sido discutido, aprofundado e modernizado: sempre no sentido de que a sua eficiência seja cada vez mais alcançada. (Biasi, 1982).

Rogers (1962) já definia a adoção "como sendo um processo de tomada de decisões, através do qual um indivíduo passa de um primeiro contato com uma inovação até a decisão de um completo e contínuo uso dela".

Do momento em que o pröprio Rogers estabeleceu essa definição até 1971, inúmeros trabalhos e esforços têm sido realizados na busca, como jä dissemos, de tornar o processo mais eficiente. Para ilustrar essas colocações, basta relembrar que nesses primeiros 10 anos, o próprio Rogers $\varepsilon$ Shoemaker citados por Burke e Molina Filho (1982), apresentaram mais de 1500 referências sobre as questões relacionadas com difusão e adoção de inovações tecnológicas pelos produto- 
res agrícolas. Evidentemente que essa busca constante de eficiência para o processo de difusão de tecnologia tem levado ao estabelecimento de modelos teöricos sempre e cada vez mais complexos, exatamente pelas insuficiências que eles sempre apresentam. Burke e Molina Filho (1982), identificam que tais insuficiências "se devem a problemas de duas naturezas": todo modelo é sempre uma representação simplificada da realidade. b) os conceitos explícitos ou implícitos utilizados num modelo são sempre passíveis de reinterpretação, não previstas inicialmente pelo idealizador do modelo. Evidentemente, tais perspectivas nos permitem inferir que, modelos idealizados dessa forma conduzi rão sempre a limitações de difícil superação uma vez que os seus objetivos estão centrados na ideía de que eles são construidos "com um determinado objetivo em vista e serve, desta forma, como uma ferramenta de trabalho (Burke e Molina Filho, 1982), isto é, respaldar teoricamente todos os mecanismos de transferência de tecnologia a produtores rurais. Dessa forma, além de insuficientes pela linearidade na sua concepção, tais modelos tem sido elaborados no sentido de uma ünica via: a transferência de inovaçöes tecnolögicas aos agricultores.

Não se tem identificado com frequência, na concepção teōrica desses modelos, a participação do prōprio usuário da tecnologia um dos sujeitos indispensāveis no processo, aliās, o seu mais importante componente que é o produtor.

$$
\text { Por outro lado, hà que se voltar a considerar }
$$


que, quando a insuficiência de determinado modelo é identificada, busca-se a participação do Produtor, muito mais com o propósito de se compreender os fatores relacionados com tais insuficiencias do que mesmo no sentido de que ele possa participar, de alguma forma verdadeiramente ativa, na elaboração do mode 10 .

A pesquisa sobre difusão de inovações tecnológicas na agricultura raramente tem se preocupado em determinar os critérios que orientam a experimentação na escolha de uma certa tecnologia e não de outra. Mais raras ainda, praticamente inexistentes, são as pesquisas que tentam descobrir as razões da rejeição e, portanto, da não difusão de uma dada tecnologia, no seu prōprio processo de geração. Mais frequentemente, porém, têm sido os estudos sobre os fatores associados à adoção ou à rejeição das inovações tecnológicas, procurando explicar porque determinadas tecnologias, consideradas üteis, fracassam em sua difusão.

E o que vem acontecendo com a nova variedade sintética de milho desenvolvida na ESALQ (Escola Superior de Agricultura Luiz de Queirōz) com o nome de Piranão. Desde 1968 já estava fixado e se iniciou sua divulgação. Entretanto, até recentemente, nem credenciada havia sido sua semente, tal o desinteresse por essa variedade. Pensou-se então em estabelecer um modo de levar o agricultor a experimentá-la, com vistas ao estudo dessa rejeição. 
Em relação a esse processo de transferência de tecnologia aos produtores rurais, Galjart (1976) identifica três fatores envolvidos no processo: Ignorância, impotência e não disposição. Uma inferência imediata que se coloca nesse caso è o fato de que esses fatores, em especial a ignorância e o desinteresse, estão presentes no processo de rejeição de uma determinada tecnologia por produtores, provavelmente porque tais tecnologias são totalmente estranhas ao produtor. Se, portanto, elas são estranhas, outra inferência se evidencia: o produtor não participou, em nenhum momento, do processo de sua geração. Neste caso, trata-se de propor ao produtor agrícola a utilização de algo, para ele, totalmente desconhecido. Em vista disso, é que se pode inferir que um projeto de pesquisa aplicada, elaborado nessas condições, para gerar tecnologias agronomicamente viàveis e economicamente justificāveis para produtores, perde consideràvelmente em objetivi.. dade alēm de ter dificultado o processo de adoção e posterior uti i zação da tecnologia pelo produtor.

Ainda se pode acrescentar que esse processo de transferência se desenvolve num nível de evidente intervenção em cima dos valores e realidade do produtor no sentido de induzí-lo a adotar algo, que nem sempre representa a sua demanda real.

Diante disso, o que se tem evidenciado è que as ações e programas de transferência de tecnologia têm sido en- 
gendrados no sentido de induzir o produtor a adotar uma tecnologia que nem sempre lhe interessa. Nesse caso, Pastore (1977) discutindo os fatores vinculados à não adoção, levantados por Galjart considera que "a ignorância pode ser superada com o trabalho da assistência técnica e da educação em geral a partir do momento em que permite abrir o horizonte de alternativas para o agricultor"'. Já em relação à impotência, os programas mais amplos, naturalmente implantados pelo governo, podem "atenuä-la". Quanto ao desinteresse, os atrativos decorrentes de transformações estruturais em direção à modernização, devem contribuir para eliminä-lo.

Biasi, (1982), ao tratar de "Mëtodos e Meios de Comunicação para a Extensão Rural afirma que "existem meios de comunicação que permitem persuadir a clientela de forma mais räpida e eficaz". Ainda enfatiza que "nunca se deve esquecer o essencial: que o cliente entenda e se convença". E que "o importante é o resultado final, a adoção da tecnologia"l. Para tanto é fundamental, segundo ainda Biasi, (1982), que a metodologia utilizada deve levar o homem do campo a se interessar em adotar a prätica ensinada.

Já esse mesmo processo de "Difusão de Tecnologia", desenvolvido no ámbito da unidade de pesquisa, no caso das unidades descentralizadas da EMBRAPA, tem sido profunda e frequentemente questionado a partir de reflexões envolvendo, não somente os responsáveis pelo desenvolvimento dessa ärea 
de atividades mas, também buscando a participação de professores de Universidades e os prōprios pesquisadores da ärea biolögica. Os resultados desses esforços de reflexão, que jä se prolongam por mais de 8 anos, começam a mostrar alguns resultados positivos, principalmente quando se evidencia jä a existência de um conjunto de diretrizes capaz de melhor nortear as ações da Difusão de Tecnologia na EMBRAPA. Tais esforços de reflexão permitiram a clara compreensão do modelo da EMBRAPA que propunha, como inovação, o estabelecimento de um programa de pesquisa assentado na interdisciplinaridade, principal característica que diferenciava este modelo do anterior, que era essencialmente monodisciplinar.

Evidentemente, näo tem sido tarefa muito fäcil o estabelecimento e operacionalização de tais diretrizes, principalmente porque nelas e na pröpria definição do conceito de "Difusão de Tecnologia na EMBRAPA" é que se podem identificar as principais características diferenciais com esse conceito de Difusão de Tecnologia mais clässico. Na EMBRAPA portanto, "difusão de Tecnologia" è um conjunto de açōes baseado no conceito de interdisciplinaridade para dentro e para fora da Empresa, tendo nos Sistemas de Produção um reforço metodolögico para as atividades de pesquisa e um instrumento de divulgação de resultados. Por outro lado, a "Difusão de Tecnologia" deve participar das diferentes etapas da pesquisa (identificação do problema, geração, transferência e adoção de tecnologia e dos mecanismos de retroalimentação). 
Em relação portanto ao Piranão, um dos objetos do presente estudo, pretende-se, antes de caracterizá-lo como uma inovação tecnológica, tecer algumas considerações sobre o Milho de modo geral, no contexto sócio-econômico brasileiro.

No processo de produção agrícola brasileiro o milho (Zea mays L.) constitui um dos mais importantes componentes. Em primeiro lugar hà que se fazer referēncia à sua importância econômica e social; tem a maior àrea de terra no país alocada para a sua produção - 12 milhões de hectares, tem o maior contingente humano dedicado à sua produção mais de 3 milhões de produtores (Programa de Difusão de Tecnologia - EMBRAPA/CNPMS, 1984). Ainda é o principal fornecedor de insumos alimentícios para as atividades de criação animal e ë uma cultura de inquestionāvel expressão nacional, uma vez que é cultivada de norte a sul do Brasil. (Programa Nacional de Pesquisa de Milho EMBRAPA/CNPMS, 1984).

Um outro aspecto que merece referência, ilustrado nas Tabelas 1 e 2, a seguir, é que o maior volume da produção brasileira de milho, em torno de 59\%, é produzido por produtores que cultivamentre 1 e 10 ha de milho e esse contingente humano ativo da produção representa $94 \%$ do total dos produtores de milho no Brasil. 
.10.

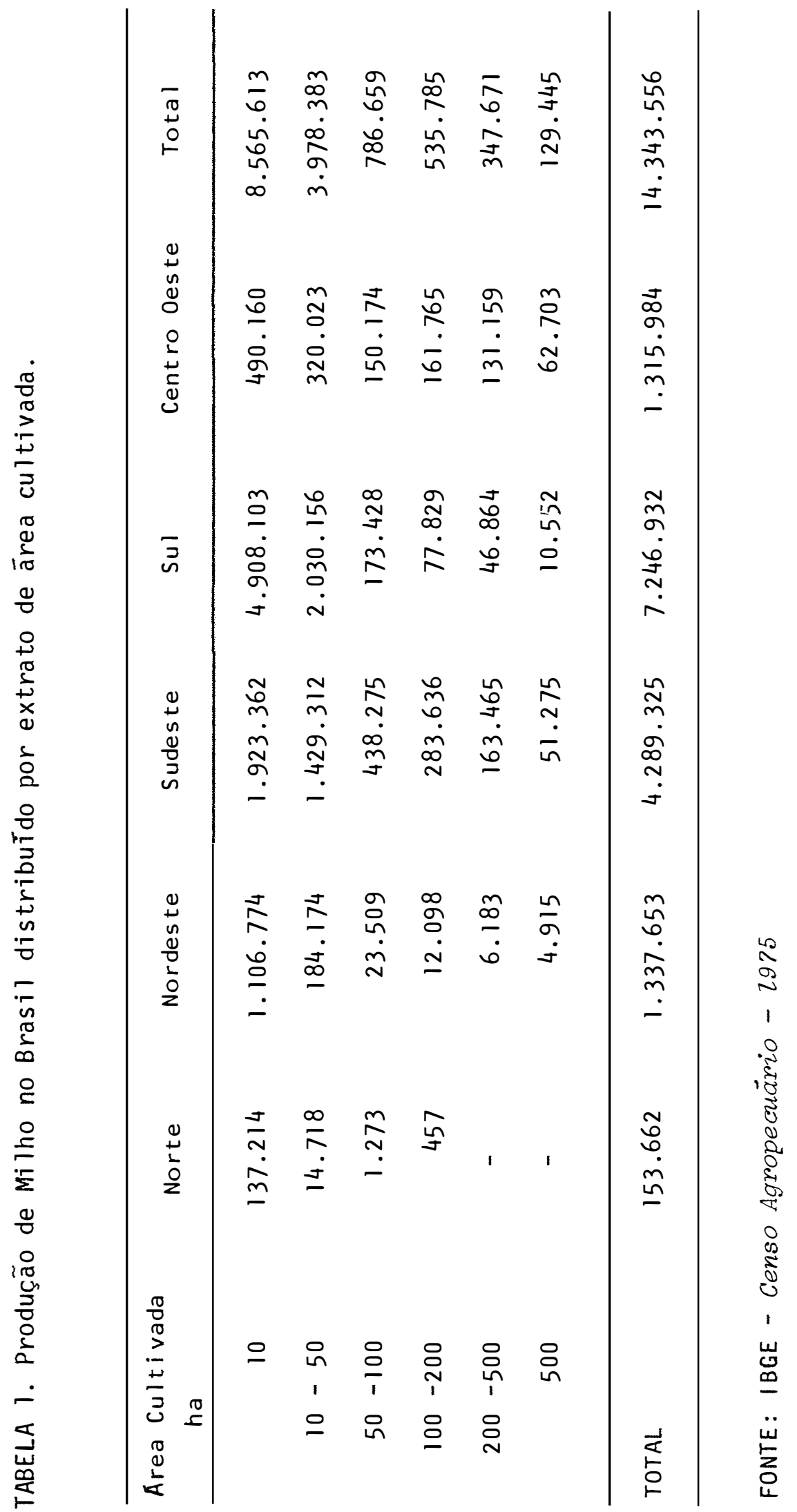


.11

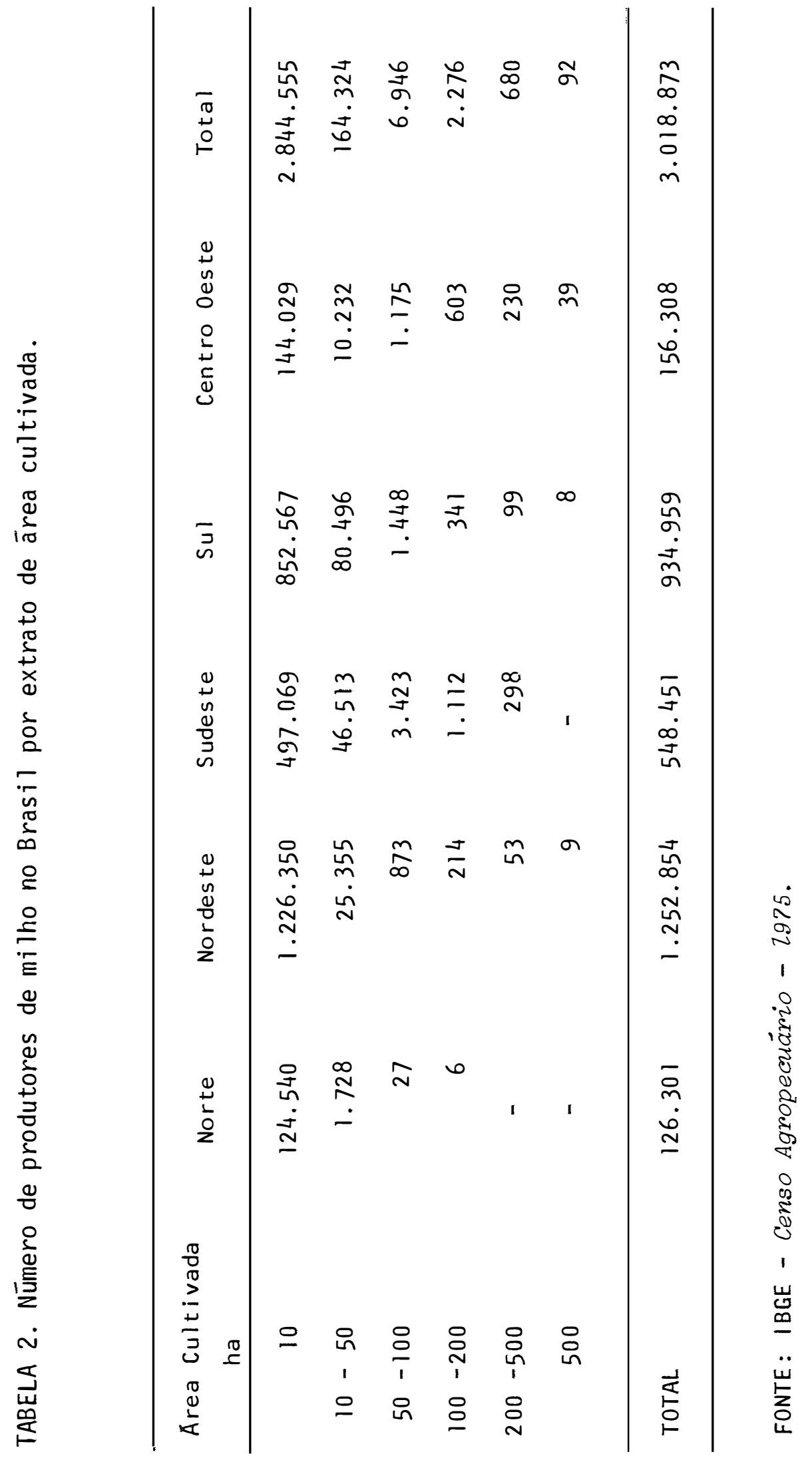


2. O Milho Pi ranão Como Uma Inovação Tecnolögica

o caráter de inovação tecnolōgica conferido ao "Milho Piranão" se assenta, bàsicamente, no seguinte fato: os milhos "normais" - assim conhecidos como aqueles milhos cultivados em larga escala e quase exclusivamente pelos produtores agrícolas brasileiros - apresentam uma característica fundamental: São milhos que apresentam plantas de porte alto e, proporcionalmente, pontos de inserção da espiga no colmo, tambēm altos. Esses milhos têm sido discutidos como materiais muito sujeitos a "acamamento" - tombamento da planta ao solo, e "quebramento do colmo" o que leva, igualmente à sua queda ao solo.

os pesquisadores que têm trabalhado em programas de melhoramento de milho e que se dedicam a encontrar formas de reduzir o porte dos milhos ditos normais, têm usado como um dos argumentos mais fortes a idēia de que a redução do porte da planta que, associada a outras características agronómicas, proporciona maior resistência ao acamamento e quebramento do colmo. Alcançados esses objetivos, admitem eles, esses materiais se tornam mais eficientes, principalmente pela redução de perdas que tais materiais de porte mais baixo apresentam com a colheita mecânica.

Dessa forma, Paterniani (1973) considera que "... no Brasil os milhos cultivados tanto os híbridos como variedades melhoradas apresentam no geral, plantas demasiado al- 
tas. Com o gradativo progresso da agricultura, tornando-a cada vez mais tecnificada, fica mais premente ainda a necessidade de se contar com plantas mais eficientes, mais facilmente adaptadas à colheita mecânica, o que é conseguido com plantas de porte bai $\times 0^{\prime \prime}$.

Por outro lado, plantas de porte baixo "permitem maiores densidades populacionais que pode resultar, dentro de certos limites, um aumento de produtividade" (Rissi $1976)$

Ainda Rissi (1976), confirma que "a altura da planta é um carāter cuja importância tem sido acentuada pelos melhoristas de milho, principalmente apös o advento da colheita mecânica.

Valva (1975), considera que "o desenvolvimento de cultivares de milho com plantas de porte mais baixo está merecendo cada vez maior atenção. E esse um dos problemas prioritärios no país". (grifo nosso).

Tais considerações nos permitem inferir que o processo de produção de milho no Brasil tem-se desenvolvido com a utilização de materiais (plantas) de porte alto e que esforços de pesquisa necessitam ser feitos no sentido de se gerar um material de porte mais baixo dando-se a essa perspectiva uma prioridade fundamental.

Segundo Rissi (1976), as plantas de milho de porte baixo, podem apresentar duas características diferentes: 
aquelas que apresentam porte baixo em função da presença de genes maiores e aquelas cujo porte baixo se deve à presença de polígenes moderadores de altura da planta.

No grupo das primeiras, podemos citar, então, o milho piranão, gerado a partir do "cruzamento efetuado em 1965 do Piramex III com o Tuxpeño braquítico; obtido no CIMMYT (Centro Internacional de Mejoramento de Mays y Trigo). Posteriormente, a população braquítica foi submetida a três ciclos de seleção massal e três ciclos de seleção entre e dentro de famílias de meios irmãos. As plantas resultantes desse processo apresentam porte baixo, colmo grosso, muito resistente ao acamamento e boa produtividade. O porte baixo conferido a essa variedade sintética deve-se ao fato de que, por influência do gene br-2 (que é um gene maior), os internódios se encurtam mantendo-se, todavia, o mesmo nümero de folhas dos milhos normais, o que confere ao Piranão a mesma capacidade fotossintética dos milhos normais". (Paterniani et alii 1977).

Dessa forma, portanto, os melhoristas podem contar com duas alternativas metodológicas para trabalhos, no sentido de reduzir o porte das plantas de milho no Brasil. Como essa perspectiva constitui uma inovação tecnológica e que num primeiro momento se fez opção pela adoção do método de introdução do gene braquítico br-2 é que se justifica. o estudo dos critérios que nortearam os pesquisadores a realizarem um trabalho de pesquisa no sentido de reduzir o porte 
das plantas de milho cultivadas no Brasil.

Tais considerações remetem a três problemas băsicos, em que o presente estudo se deterá com mais detalhes:

1. Existem tecnologias consideradas üteis que são rejeitadas pelos produtores.

2. A pesquisa monodisciplinar nem sempre está atenta ao seu contexto social.

3. A difusão de tecnologia tem sido mal compreendida, a partir do momento em que sua operacionalização não tem contemplado todas as etadas do processo da produção, desde a identificação do problema de pesquisa até a adoção das tecnologias pelos produtores.

Assim, objetiva o presente estudo identificar os fatores vinculados ao processo de geração e adoção do milho Piranão e que podem estar relacionados à sua rejeição. 


\section{REFERENCIAL TEORICO}

1. Aspectos Histöricos da Pesquisa Agrícola no Brasil

A atividade de pesquisa agropecuäria no Brasil pode ser analisada a partir da compreensão de duas fases histōricas bem definidas: a primeira, que se iniciou desde o século passado (por volta de 1870), e se cristalizou a partir de uma filosofia tipicamente monodisciplinar, que foi sendo transferida de geração a geração de pesquisadores, atē 1972 ; a segunda que, com o advento da EMBRAPA, propõe um modelo de pesquisa agropecuäria fundamentado numa teoria essencialmente interdisciplinar.

E de suma importância algumas considerações mais detalhadas sobre o conceito de monodisciplinaridade, para que se tenha uma idēia mais clara do divisor histōrico da pesquisa agricola no Brasil e de quais fatores contribuiram para a cristalização de um modelo de pesquisa monodisciplinar

$$
\text { Pastore (1977), ao analisar o problema da cria- }
$$


tividade na pesquisa agrícola, abordou a ótica Econômica, a ötica Psicológica e a ótica Sociolögica como componentes fundamentais da criatividade manifesta desenvolvida pelos pesquis adores.

Para ilustrar as idéias a serem levantadas, serão consideradas apenas as abordagens econômicas e sociológicas (organizacionais), pois elas bem podem fundamentar os objetivos desta discussão.

"A importância de se abordar aqui os aspectos económicos relacionados com a atividade da pesquisa agrícola, reside no fato de que eles apresentam uma lógica que contribui sobremodo para a compreensão das características da pesquisa agrícola desenvolvida no Brasil" (Schaun 1981).

Alves e Pastore (1977), ao se referirem às questões relacionadas com a pesquisa agrícola no Brasil, alinharam as seguintes considerações: "A literatura sobre os aspectos económicos e institucionais da pesquisa agrícola apresentou uma grande expansão a partir de 1971, estimulada, em grande parte, pelo trabalho de Hayami e Ruttan (1971). o raciocínio central desse trabalho é que a pesquisa agrícola é uma atividade induzida por forças económicas e sociais, em particular, pelo preço relativo dos fatores de produção e por um processo dialético de pressão dos agricultores sobre os pesquisadores. Esse sistema de forças seria, assim, responsävel não somente pelo volume de tecnologia gerada por uma so- 
ciedade mas, principalmente, pelo tipo de tecnologia produzida como resposta aos preços dos fatores. Por exemplo, a elevação substancial do preço e a dramātica escassez de terra no Japão, induziu o sistema de pesquisa agrícola japonès a gerar tecnologias químicas e biológicas, cujo impacto fundamental naquele país concentrou-se na descoberta de variedades de cereais de alta produtividade e de alta resposta a fertilizantes (Hayami e Akino, 1975). Como exemplo, no outro extremo, Hayami e Ruttan colocam as tecnologias mecânicas geradas maciçamente nos Estados Unidos como resposta ao elevado custo de mão-de-obra naquele país, trazendo como resultado, um sensível aumento da produtividade do trabalho. Dessa forma, as forças econômicas podem ser consideradas como as grandes determinantes do caminho do desenvolvimento do sistema de pesquisa. Alèm delas, os autores destacam a importância da interação íntima e contínua entre agricultores e pesquisadores os primeiros solicitando soluções e os segundos respondendo àquelas demandas. Assim, os projetos, programas e as próprias instituições de pesquisa vão tomando a sua forma prōpria que pode ser entendida como reflexo de um complexo sistema de forças econômicas e sociais".

"Um aspecto que merece ser expandido no modelo de Hayami e Ruttan, diz respeito ao processo interativo entre a oferta e a demanda de tecnologia. Provavelmente, esse tipo de interação pode ser enquadrado dentro do chamado processo de causação circular e cumulativo: os grupos de interesse, in- 
cluindo os grandes fazendeiros comerciais, as elites rurais, os empresários de área agro-industrial e outros, atuaram naqueles países como elementos de pressão com expectativas muito claras quanto à possibilidade de derivarem lucros das tecnologias químicas, biológicas e mecânicas. No outro lado do "continuum" estava a estrutura político-administrativa representando também certos grupos de interesse como os burocratas, os pesquisadores, a comunidade científica e outros, cuja responsabilidade central era a geração dos bens públicos. A sensibilidade de resposta, assim como a intensidade e o viés no atendimento aos apelos do mercado, evidentemente, variaram de país para país e de época para época. Como vimos, no Japão, os produtores passaram a exigir variedades que permitissem economizar terra e o sistema de pesquisas respondeu velozmente com uma grande coleção de novas variedades; nos Estados Unidos, os próprios fazendeiros, mais avançados, iniciaram, no século passado, pequenos experimentos com maquinaria agrícola visando a economizar mão-de-obra, obtendo, em seu socorro, um pronto atendimento das indūstrias e instituições de pesquisa que, aperfeiçoando aqueles protótipos, facilitaram o setor industrial a oferecer no mercado, em 1980, mais de 200 tipos de arados e implementos (Evenson, 1974). Nessa mesma época, foi a pressão dos melhores e mais ricos fazendeiros e de suas organizações que induzirama estrutura político-administrativa a criar a rede de estações experimentais dos Estados Unidos (Paterson e Fitzhanis, 1975)". 
Com base nos componentes teöricos alocados acima de Hayami e Ruttan, sobre oferta e demanda por tecnologias agrícolas, tomemos o caso do Brasil, para estabelecer o seguinte raciocínio: se no Brasil, desde o início de sua colonização, sempre houve abundância de terra e de mão-de-obra, estes dois fatores não poderiam atuar como forças capazes de induzir um grande desenvolvimento na atividade de pesquisa agrícola. E claro que situações mais específicas, como são Paulo, merecem ser referidas aqui, apenas para que não surjam tais fenómenos como capazes de contestar simplesmente as i déias até aqui levantadas. E que em São Paulo o crescimento do produto agrícola, jä desde a dēcada de "1950/60 e mesmo antes disto, foi devido a ganhos de produtividade da terra e do trabalho, conseguidos via utilização de tecnologias biológicas e químicas e, em certa medida, de mecanização. Naquele Estado, a escassez relativa de terra e trabalho jä exerciam as funções de indutores de pesquisa, enquanto que o resto do país continuava utilizando mais e mais esses fatores de produção" (Alves e Pastore, 1975).

Ainda é possível ilustrar empiricamente o fenómeno de São Paulo, a partir de uma ōtica sociológica. Para tanto, podemos partir do raciocínio de Peterson e Fitzhanis, citados por Alves e Pastore (1975), de que "foi a pressão dos melhores e mais ricos fazendeiros e de suas organizações que induziram a estrutura político-administrativa a criar a rede de estações experimentais nos Estados Unidos". Ora, durante 
muito tempo, o poder e o prestígio, principalmente dos cafeicultores do Estado de São Paulo, bem podem, anàlogamente, ter exercido essas pressões junto ao sistema de poder políticoadministrativo, o que contribuiu, entre os outros fatores jä abordados, para conduzir o Estado a uma posição de destaque na pesquisa agrícola brasileira em relação aos outros Estados da Federação.

Se este era o quadro brasileiro, muito pouco ou quase nada se poderia esperar de decisões expontāneas do governo em termos de maciços investimentos nas pesquisas agrícolas, que fossem capazes de gerar uma tecnologia agronómica útil e sobretudo viável para a nossa grande massa de produtores agrícolas, especialmente daqueles localizados nas categorias de camponeses, que são o nosso maior contingente ativo dedicado à agricultura brasileira.

Ora, se os fatores de produção eram abundantes, longe estariam eles de induzir uma demanda por tecnologia agrícola atravēs dos responsāveis pela produção e, portanto, nada se poderia esperar de nenhum sistema de governo até hoje ocorrido no Brasil, em termos de resposta, mediante oferta de tecnologia.

Dentro desse quadro é que se pode localizar a gênese de um componente que pretendemos aprofundar e que tem caracterizado a atividade de pesquisa agrícola no Brasil. Trata-se da Monodisciplinaridade. Senão, vejamos pelo seguinte: 
o sistema de governo, não sofrendo nenhuma pressão de demanda por tecnologia agrícola, longe estaria de fazer um investimento nesse setor, que fosse capaz de refletir um amplo e profundo desenvolvimento de um programa de pesquisa agrícola no país. Desse modo o quadro que se desenvolveu no Brasil nesta àrea foi profundamente desestimulante para a formação e desenvolvimento de um elenco de pesquisadores compatível com as características naturais do Brasil do ponto de vista pelo menos ecológico de um país tropical de dimensões continentais e que deveria estar, portanto, a esta altura, pelo menos na vanguarda da produção de alimentos para o mundo. Se a pesquisa agrícola no Brasil conseguiu sobreviver, mesmo precariàmente, isto deve ser creditado à obstinação e verdadeiro sacerdócio de alguns poucos quadros de pesquisadores que conseguiram resistir às forças conträrias, caracterizadas por uma total insensibilidade frente aos problemas da agriculturabrasileira e por limitada visão do que poderia representar o setor primärio para a economia brasileira.

Haja vista o que nos dizem Alves e Pastore (1977): "Os dados disponíveis indicam que na década de 50, exatamente na euforia da industrialização, os governos federal e estadual, reduzi ram os recursos para as instituições de pesquisa agrícola, sendo que muitas delas foram simplesmente eliminadas". E esse fenōmeno não deixou de contribuir fortemente para que esses pesquisadores fossem obrigados, para a sua prōpria sobrevivência material, a uma atividade de pesqui- 
sa dentro de uma ötica exclusivamente monodisciplinar. E isto era pouco para as nossas perspectivas históricas.

Se o quadro era limitado, os recursos cada vez mais escassos, os estímulos aos pesquisadores através de cursos de especialização e pós graduação eram reduzidos ao mínimo possível, não se permitia a ampliação dos quadros de pesquisadores a níveis compatíveis com as prōprias exigências naturais do trabalho. Os pesquisadores ainda se obrigavam a demandar esforços pessoais para angariar recursos necessärios ao financiamento dos seus projetos; enfim, todo um fenômeno de profundo desinteresse por parte dos governos em relação aos problemas agrícolas, obrigavam os pesquisadores a uma atividade de pesquisa cada vez mais específica e tênue. Isto contribuiu sobremodo para que o pesquisador limitasse a sua atividade de pesquisa ao estudo de uma ünica disciplina onde, inclusive, buscava, nas bibliotecas e nos colegas mais experientes, as suas principais fontes de inspiração para a investigação. Evidentemente, não se pretende formar no pesquisador um especialista em generalidades onde, porisso, não se consegue o aprofundamento do conhecimento nas especializações, necessärio ao trabalho verdadeiramente científico. Mas o que em verdade não se conseguia era formar, dentro de uma unidade de pesquisa, uma equipe multidisciplinar, onde os especialistas em diversas àreas com conhecimento sobre um determinado sistema agrícola pudessem, no aprofundamento da sua àrea específica de conhecimento, identificar as conexões in- 
terdisciplinares com os outros componentes daquele sistema agrícola em estudo. Em outras palavras, o que se encontrava com bastante frequência nessas unidades era uma equipe de pesquisadores onde, por exemplo, um se dedicava ao estudo de entomologia do Milho, outro se dedicava ao estudo de präticas culturais em Algodão, outro mais a estudo de melhoramento de Feijão e assim, o que se conseguia, em melhor hipötese era o estudo de uma disciplina do sistema milho, outra disciplina do sistema algodão, outra disciplina mais do sistema Feijão, o que permitiu o desenvolvimento desse caräter monodisciplinar realizado pelo pesquisador agrícola brasileiro.

Senão, vejamos que as unidades de pesquisas agrícolas construidas no Brasil, obras paradoxalmente muitas vezes suntuosas, abrigavam um elenco de pesquisadores que levaram, às vezes, anos sem receber recursos sequer para o custeio de um experimento, juntando-se a isto o fato de as unidades trabalharem com muitos produtos agrícolas, como o antigo IPEACO (Instituto de Pesquisa e Experimentação Agropecuãria do Centro-0este), por exemplo, que antes de ser o CNPMS (Centro Nacional de Pesquisa de Milho e Sorgo), chegou a trabalhar em pesquisa com dezesseis produtos. Ora, desenvolver uma tarefa dessas, e contando com um nümero limitado de pes quisadores, era impossível estabelecer-se um programa de pesquisa, onde se pudesse trabalhar com todos os componentes de um sistema. A tudo isto, soma-se ainda a profunda influência sofrida do estilo europeu de pesquisa, caracterizado por 
ideias tipicamente liberalistas e que provavelmente devem ter contribuido para um "modelo difuso" de pesquisa agrícola no Brasil, cristalizando a forma monodisciplinar de pesquisa. Contador (1975) ao interpretar os estudos de José Pastore e Eliseu Alves sobre os primōrdios da pesquisa agrícola no Brasil, confirmou que "o sistema individualista de pesquisa do modelo difuso, importado de outros países, tambēm dificultou a comunicação entre o cientista-pesquisador e a realidade econômica do país".

Tal modelo de pesquisa sedimentado nesses componentes e ainda enriquecido por outros fatores histōricos, políticos e ideolögicos não poderia aspirar, como de fato não aconteceu, assumir uma postura em que a agronomia se constituisse num verdadei ro fator de desenvolvimento ou, mesmo, de modernização plena da agricultura brasileira.

E tudo isto, num espaço de tempo de mais de um século (que é a idade da nossa pesquisa agrícola), só poderia resultar numa estrutura comportamental cristalizada, onde uma proposta como a da EMBRAPA só pode encontrar reações às vezes negativas e uma certa dificuldade de que tal proposta obtenha, a curto prazo, ressonância unānime no contingente de pesquisadores agrícolas brasileiros. Na verdade, a abordagem desses aspectos histöricos alimenta a perspectiva de se poder, atravēs deles, compreender com maior clareza a idéia jä abordada de que a EMBRAPA, mediante sua proposta de um mode- 
lo interdisciplinar de pesquisa, representa verdadeiramente um divisor histórico da pesquisa agrícola no Brasil.

Uma anālise crítica e uma profunda reflexão sobre os problemas levantados anteriormente, conduziu ao raciocínio de que tal panorama necessitava de uma mudança, onde o modelo de pesquisa agrícola no Brasil até então vigente, pudesse oferecer perspectivasmais amplas para atender àquela demanda por tecnologia agrícola, que já começava a se manifestar. Isto, porque já se havia chegado ao consenso de que as fronteiras agrícolas são finitas e as āreas mais férteis do país estavam com seus limites praticamente atingidos.

E a partir desse esforço de reflexão, desenvolvido dentro de uma ötica essencialmente dialética, assentada na necessidade, de que os pesquisadores conseguissem - numa primeira etapa da pesquisa, qual seja a identificação do problema - obter um conhecimento real das demandas e necessidades tecnológicas dos produtores-e isto só seria possível mediante uma anālise crítica profunda da própria realidade atual da produção - a partir de que poderiam ser elaborados projetos de pesquisa realmente compatíneis com essa realidade e nela inspirados em essência e plenitude. Dentro desse escôpo, então, è que foi proposto um novo modelo de pesquisa agrícola para o país, obedecendo a uma perspectiva interdisciplinar, e a ser desenvolvido pela EMBRAPA. Tal perspectiva nada mais é do que o esforço dos pesquisadores, no sentido de com- 
preenderem com maior clareza quais as formas de interação existentes entre a disciplina da sua especialidade es outros componentes do sistema de produção. Para tanto, as primeiras medidas propostas se refletiram numa modificação das características das unidades de pesquisa do Ministērio da Agricultura, caracterizadas pelos antigos Institutos de Pesquisas Regionais e que pesquisavam värios produtos, sem se amarrar, entretanto, a um sistema completo de pesquisa.

Foram então criados os Centros Nacionais de Pesquisa, estruturados para trabalhar com, no mäximo, três produtos agrícolas. Não se pretende descer a detalhes do organograma proposto para as unidades de pesquisa da EMBRAPA, porque este não é o objetivo principal deste estudo. No caso específico do Centro Nacional de Pesquisa de Milho e Sorgo, uma das expectativas dessa estruturação foi a de que ela viesse a facilitar ou contribuir para que seus pesquisadores incorporassem de forma mais räpida e segura a idéia de interdisciplinaridade. Isto se tornou particularmente válido no momento em que se reuniu numa mesma base física pesquisadores especialistas de todas as áreas das culturas de Milho e Sorgo, incluindo-se aí a pesquisa de Sistema de Produção das duas culturas. Se por um lado, o "Sistema de Produção" constituia para a EMBRAPA um poderoso instrumento de transferência de tecnologia aos produtores agrícolas, por outro lado era de grande importância como método operacional do trabalho experimental, para a compreensão clara da idéia de interdiscipli- 
naridade.

Acontece que essa perspectiva foi de alguma forma desprezada e se fixou o "Sistema de Produção" através de "Pacotes Tecnolögicos", apenas como instrumento de transferência de tecnologia. Com isto, percebemos que estamos desprezando este poderoso recurso metodológico que é o Sistema de Produção capaz de contribuir efetivamente para a consecução dos objetivos operacionais da EMBRAPA, que é a realização de uma prätica de pesquisa dentro de uma perspectiva interdisciplinar.

E imprescindível aqui, algumas considerações sobre o conceito e a idéia de interdisciplinaridade, com vistas a superar algumas düvidas de interpretação que frequentemente ainda observamos, não somente em pesquisadores de outras instituições, como tambēm entre componentes do quadro da EMBRAPA.

Em primeiro lugar, a idéia de um modelo interdisciplinar de pesquisa constituiu o objetivo operacional da empresa e esta passou a ser sua proposta de trabalho. Daí até se entender que isto constituia uma imposição institucional para seus pesquisadores, vai uma diferença muito grande. 0 fato de um pesquisador ter como perspectiva operacional de trabalho uma tradição cristalizada em mais de um século de experiência, lhe confere um tal comportamento, que qualquer proposta de mudança nesse sentido não vai, via de regra, encontrar guarida fäcil nesse pesquisador. Isto merece referên- 
cia porque a interdisciplinaridade precisa ser encarada, antes de tudo, como uma proposta e não como um modelo a ser imposto. Na verdade, a opção de interdisciplinaridade a ser feita pelo pesquisador deve ser resultado de uma atitude es sencialmente subjetiva e, portanto, pessoal. Assim sendo, surge a questão: por que grande parte dos pesquisadores ainda não adotou essa atitude de mudança? Vemos duas causas bási cas: ou porque eles não conhecem, em plenitude, o conceito, ou porque eles não o aceitaram como välido. A experiência, todavia, tem mostrado que a relutância por parte do pesquisador em relação à adoção de nova postura de pesquisa parece residir em dois fatores fundamentais: no conhecimento limitado que ele tem do conceito e no caräter psicológico, visto que a interdisciplinaridade, de alguma forma vulnerabiliza a àrea de segurança pessoal do pesquisador.

Em segundo lugar, é preciso ficar definitivamente claro que o fato de a EMBRAPA propor um modelo de pesquisa interdisciplinar não significa em hipōtese alguma, ter ela negado ou mesmo contestado a monodisciplinaridade. Muito pelo conträrio, a monodisciplinaridade é uma fase indispensävel na atividade de pesquisa, de vez que, nessa fase é que se manifestam todas as potencialidades do pesquisador em relação à formação do conhecimento cientifíco, sem cujo exercício dificilmente se poderia atingir a fase subsequente do processo, que è a tecnologia viável para o desenvolvimento do processo de produção agrícola. 
A experiência acumulada no CNPMS tem revelado fenômenos extremamente välidos como ilustrativos dessa situação, razão por que julgamos importante referenciar aqui, um fato, como fundamentação empírica às idēias anteriormente expostas. Trata-se, por exemplo, do problema observado pelos pesquisadores de Entomologia do CNPMS, em relação às pragas de grãos armazenados, de quem obtivemos o seguinte depoimento: "O ataque de pragas de grãos armazenados tem sido, por longo tempo, um problema sërio para os agricultores que armazenam mi lho em suas propriedades. Värios trabalhos jà foram conduzidos visando encontrar a solução; porëm, a despeito das tentativas de controle das pragas, exercida pelos produtores, o problema sō vem aumentando.

Preocupados com este problema, que afeta, principalmente, os pequenos produtores, pesquisadores do CNPMS iniciaram um trabalho de pesquisa no qual participaram ativamente o produtor, o extensionista e o pesquisador.

o trabalho se iniciou com a elaboração de um questionärio, atravēs do qual se pretendia conhecer de perto a gravidade do problema - armazenamento de milho a nível de fazenda. De posse deste questionärio, pesquisadores do CNPMS e EPAMIG (Empresa de Pesquisa Agropecuāria de Minas Gerais) percorreram as principais regiöes produtores de milho do Estado de Minas onde, apös se encontrarem com extensionistas de escritörios locais da EMATER-MG (Empresa de Assistência Tëc- 
nica e Extensão Rural do Estado de Minas Gerais), visitarem em torno de 800 produtores com a finalidade de constatar, in loco, a natureza, causa, intensidade e possíveis soluções para o referido problema.

Com a anälise do questionärio aplicado foi constatado que o problema existe em função de um controle inadequado das pragas, de estruturas armazenadoras (paiōis) tecnicamente mal construidas e também acredita-se que o mal empaIhamento dos híbridos comerciais tem concorrido para o agravamento da situação.

Com base na experiência adquirida pelo contato com extensionistas e produtores, iniciou-se um projeto de pesquisa objetivando encontrar soluções alternativas para o controle de pragas no milho armazenado em espigas. 0 primeiro passo desta pesquisa foi promover um levantamento por amostragem do milho armazenado nos paióis de fazendas localizadas nas principais regiões produtoras de milho em Minas Gerais. A anälise das amostras indicaram que o grau de carunchamento no período entre a colheita e os meses de agosto/81, novembro/81 e março/82 foi respectivamente 17,36 e $45 \%$ dos grãos. Foi tambëm observado que o milho daqueles produtores que utilizaram inseticidas em pó a base de malathion, aplicado em camadas alternadas com mi lho, estava tão carunchado quanto o milho dos produtores que não aplicaram nenhum inseticida. 
uma infraestrutura de paióis de diversos modelos onde se pudesse testar värias alternativas no controle de pragas do grão de milho.

No primeiro ano de estudos se observou que o tipo de paiol tem muito pouco ou nenhuma influencia no comportamento dos insetos, isto é, o ataque dos insetos foi em igual intensidade nos paióis de tábuas, madeira roliça e tela. Excessão feita ao paiol de alumínio, fechado, mais abafado, onde os insetos proliferaram mais e causaram maiores danos

Com relação aos métodos de controle se observou que no paiol testemunha (milho sem qualquer tratamento) o miTho foi tão carunchado quanto aquele tratado com malathion pó. Os melhores tratamentos foram aqueles em que o milho foi expurgado antes de ser armazenado; porém, não houve diferença entre o tratamento expurgo + malathion pó e o expurgo somente. Um expurgo do milho em palha sob lona plästica, antes de armazenar o milho, associado a prätica de limpeza e desinfestação do paiol reduziu o dano a menos da metade em relação a testemunha.

Estes resultados foram levados aos produtores através de dias de campo no CNPMS e os extensionistas estão promovendo demonstrações de resultados da pesquisa junto aos produtores, atravēs de Unidades de Demonstração".

$$
\text { Vê-se por isto, que em nenhum momento a fase }
$$


monodisciplinar da pesquisa foi contestada ou mesmo violentada. O entomólogo utiliza seus conhecimentos de Entomologia, o especialista em Engenharia Agrícola os de Armazenamento, sugerindo modelos de paióis e todos se enriquecem, no momento em que percebem, na prática, que a interação entre sua ärea e as outras componentes do Sistema, ē um fato evidente, palpável e, portanto, indispensāvel na formulação de uma recomendação técnica ou mesmo científica. Já os produtores, por sua vez, contribuiram sugerindo o uso da folha de eucalipto que, quando usada como medida complementar ao expurgo, mostrou ser eficaz como repelente aos insetos. 


\section{A Perspectiva Interdisciplinar no Processo da Pesquisa}

Julga-se aqui necessārio algumas considerações, a respeito do conceito de Multidisciplinaridade abordado no modelo Institucional da EMBRAPA e do conceito de interdisciplinaridade discutido e aprofundado por JAPIASSU (1976). As razões principais para esse esforço de aproximação conceitual estäo na necessidade de se estabelecer o rigor científico que - escopo do presente trabalho requer e pelo fato de que, embora utilizado como conceitos diferentes, têm sido definidos de forma profundamente parecida, senão idêntica.

Tome-se então algumas definições do conceito Interdisciplinaridade:

"A exigência interdisciplinar impõe a cada especialista que transcenda sua própria especialidade tomando consciência dos seus próprios limites para acolher as contribuições das outras disciplinas". (Japiassu, 1976). Para Japiassu o caráter interdisciplinar se manifesta no "contexto das chamadas pesquisas orientadas, concertação ou convergência de värias disciplinas com vistas à resolução de um problema cujo enfoque teörico está, de algum modo, ligado ao da ação da decisão".

Ainda Japiassu (1976) identifica o "fenômeno interdisciplinar como nova maneira de encarar a repartição epistemolögica do saber em disciplinas e das relações entre elas". 
Uma questão crucial, discutida por

Japiassu

(1976) consiste em considerar que o caräter interdisciplinar não pode ser colocado como "uma panacéia científica"l mas deve, isto sim, ser aprofundado sem perder de vistas as "características sociais e intelectuais da comunidade de pesquisadores"; e podemos ampliar essa perspectiva para a idēia de que a prōpria realidade da produção agrícola, palco natural do labor da pesquisa agropecuäria, não pode estar ausente nas reflexões interdisciplinares. Dessa forma è que ".... os encontros entre especialistas não serão considerados como simples trocas de dados, pois não se pretende chegar a um empirismo compósito, codificado para fins de ensino. Pelo conträrio, esses encontros. serão considerados o lugar e a ocasião em que se verificam verdadeiras trocas de informações e de críticas ........em que o espírito de concorrência e de propriedade epistemolögica entre os pesquisadores devem ceder o lugar ao trabalho em comum, de busca de interação entre duas ou mais disciplinas ......."(JAPIASSU, 1976).

Tomados então os elementos acima, como capazes de caracterizar, na ótica de Japiassu, o conceito de Interdisciplinaridade, veja-se outros elementos que, na ötica da EMBRAPA, buscam caracterizar o conceito de Multidisciplinaridade: Blumenschein (1977) identifica que a "EMBRAPA foi idealizada e tem sido estruturada e implantada com clara finalidade de buscar soluções para os problemas do agricultor brasileiro". Assim, "para atingir metas com esse nível de obje- 
tividade, é importante adotar uma estratégia onde os Pesquisadores estejam em constante envolvimento. (grifo nosso) com Produtores, Consumidores e Extensionistas ...". Percebe-se claramente aqui, que o caräter de constante envolvimento. entre Pesquisadores, Consumidores, Produtores e Extensionistas apresenta uma tal convergência com o enfoque das pesquisas orientadas num "concerto de que participem värias disciplinas ........ discutido por Japiassu, que não vemos dificuldade em aproximar, considerando as semelhanças das definições e caracterização, o conceito de Multidisciplinaridade, na ótica da EMBRAPA, do de Interdisciplinaridade, na ótica de Japiassu. Ainda num esforço de aprofundar e melhor justificar essa proposta de aproximação, vejamos outras citações de Blumenschein (1977): "... Com esse enfoque, pode-se distinguir, dentro do processo de pesquisa, tres fases que merecem considerações especiais: levantamento e definição de problemas que requerem solução atravēs da pesquisa, geração de tecnologia, verificação e medição de interações (grifo nosso) e a ação do pesquisador na divulgação dos resultados". Ainda segundo Blumenschein (1977), "Os Pesquisadores, em geral são especialistas em disciplinas como Genética, Melhoramento, Fitopatologia, etc e sua tendência natural é a de concentrar a atenção exclusivamente nos problemas referentes à sua especialidade. Contudo, maior produção e produtividade não resultam unicamente da ação isolada do material genético usado ou de maior ou menor eficácia no combate a pragas e doenças ou na quali- 
dade, formulação e forma de aplicação de fertilizantes, ou no manejo correto das culturas e animais, etc. mas elas originam-se do somatório das ações individuais desses componentes, da interação entre eles e com o meio ambiente. 0 Pesquisador especialista, empolgado com sua disciplina pode descuidar das interações que, na maioria das vezes, são mais importantes do que as ações isoladas de natureza monodisciplinar".

Finalmente, "a estruturação das instituições de Pesquisa pode predispor os Pesquisadores para o enfoque multidisciplinar. Para isto ele deve evitar a compartimentalização monodisciplinar optando por equipes multidisciplinares que se encarregam de produtos ou problemas de maneira integrada". Blumenschein, (1977).

Poder-se-ia levar eśsa questão conceitual a nrveis de discussão muito mais profundos porém, conforme foi antes esclarecido, acredita-se bastante essas considerações, para justificar, a partir daqui, a adoção do conceito Interdisciplinar, em lugar do Multidisciplinar. Isto, naturalmente, por uma questão de coerência teórica, de vez que ele é especificamente estudado e aprofundado por Japiassu.

o que precisa ser compreendido, todavia, è que a EMBRAPA se tem estruturado a partir da montagem de equipes Multidisciplinares porque, em verdade, o que existe nas unidades de pesquisa da EMBrApa é uma equipe de especialistas nas diversas disciplinas que compõem os sistemas agricolas es- 
tudados por essas unidades. A perspectiva todavia è de que essas equipes, que têm uma característica essencialmente multidisciplinar possam realizar uma frätica de pesquisa dentro de uma perspectiva interdisciplinar, porque um dos objetivos operacionais da EMBRAPA é, realmente, a adoção da interdisciplinaridade no labor científico da pesquisa e geração de tecno$\operatorname{logia}$

Buscou-se, com essas considerações caracterizar, em primeiro lugar, a interdisciplinaridade como um dos objetivos operacionais da EMBRAPA e, em segundo lugar, defi nir este conceito como o esforço que deve ser desempenhado pelos pesquisadores no sentido de identificar com a necessäria clareza quais as conexões que existem entre os diversos componentes de um determinado sistema. No caso do presente trabalho, do sistema de produção de milho. A respeito da interdisciplinaridade então, ainda se tem a considerar que "quanto mais se desenvolvem as disciplinas do conhecimento, diversificando-se, mais elas perdem o contato com a realidade humana", e que a exigência interdisciplinar impõe a cada especialista que transcenda sua própria especialidade, tomando consciência de seus próprios limites para acolher as contribuições das outras disciplinas". (Japiassu, 1976).

Alëm disso, o esforço do presente estudo a o tentar esclarecer a ötica monodisciplinar que tem caracterizado a pesquisa agropecuäria brasileira através de 
componentes históricos e mesmo de observação empírica feita através da própria vivência com o trabalho dentro da Unidade de pesquisa não buscou uma contestação simplista, ou mesmo ingênua, dessa monodisciplinaridade. Em verdade, buscou-se, através dessas fiēis descrições, contidas no ítem anterior, mostrar o caräter monodisciplinar vigente e a necessidade de uma profunda reflexão sobre essa realidade. Espera-se que esse esforço de reflexão seja uma preocupação constante de todos os pesquisadores, em que o frequente questionamento e a anālise crítica constante, possam contribuir para a compreensão de que a perspectiva interdisciplinar no labor científico é, não somente viāvel mas, sobretudo, extremamente urgente. Por outro lado, há que se considerar que a dificuldade de se adotar essa ótica interdisciplinar como uma perspectiva metodológica, pela sua característica complexidade, só poderá ser superada através desse esforço reflexivo, conjunto e integrado, a fim de que se possa, assim, adaptä-la às próprias peculiaridades do nosso sistema de pesquisa agrícola.

Longe de nös, portanto, a idéia de apresentar o interdisciplinar como uma panaceia científica ou como empreendimento dissociado das características sociais e intelectuais da comunidade dos pesquisadores.

Do ponto de vista essencialmente teórico, as pesquisas interdisciplinares podem surgir, segundo Japiasu (1976), de duas preocupações fundamentais. "A primeira relati- 
.40 .

va às estruturas, e aos mecanismos comuns às diferentes disciplinas científicas, chamadas a ingressar num processo de interação; a segunda relativa aos possíveis métodos comuns a serem instaurados para as disciplinas cooperantes. Essas evidências teöricas são capazes, portanto, de respaldar uma questão que tem sido o fulcro das preocupações da EMBRAPA, qual seja, aquela jà exaustivamente abordada neste estudo e que merece ser relembrada. Trata-se da ingente necessidade de profunda reflexão entre os pesquisadores, especialistas nas diversas disciplinas do sistema milho. Tais reflexões é que conduzirão à identificação das conexões entre essas diversas disciplinas e que proporcionarão a identificação dos pontos comuns existentes entre elas. Sö então a partir daí é que poderão ser estabelecidos métodos suficientemente convergentes e, portanto, capazes de nortear operacionalmente a execução da pesquisa essencialmente interdisciplinar. Naturalmente que essas duas perspectivas conduzem, invariavelmente, a duas etapas diferentes: a primeira, que constitui a etapa da reflexão e onde os conhecimentos são abordados na busca da convergência para identificação das tais conexões interdisciplinares. A segunda, que constitui a etapa da ação, precisa ser viabilizada a partir da sua conjugação com o conhecimento sem o que a objetividade operacional interdisciplinar estará fortemente comprometida. 0 exemplo, citado anteriormente, em relação ao problema do controle de pragas dos grãos armazenados, bem pode ilustrar empiricamente isto. 
Tome-se agora as duas questões teöricas cruciais que são a definição do conceito e os objetivos do método interdisciplinar. ( Japiassu, 1976), numa primeira aproximação o define a partir de uma constante crítica das fronteiras das disciplinas e de sua compartimentação. Evidentemente, isso proporciona uma grande esperança de renovação no domínio das metodologias cientificas. Entre os objetivos a que se propõe a interdisciplinaridade, o prōprio Japiassu faz referência especial a um, que merece citação por convergir profundamente com o escōpo do presente estudo: "Interdisciplinar objetiva desenvolver a preocupação de melhor guiar a pesquisa propriamente dita. Em outros termos, o que se tem em vista é a descoberta de melhores métodos para planejar e quiar a ação".... Nesse ponto è que se destaca, no processo de geração de tecnologia, a importância da objetividade na identificação do problema, o que dará os elementos necessários a um bom planejamento (projeto de pesquisa) e sua operacionalização (que ë a ação de pesquisar).

Esta questão se evidencia em tal atualidade que projetos de pesquisa estão sendo elaborados pela pröpria EMBRAPA, que assumiu o desafio de desenvolver tecnologias apropriadas a regiões específicas e contextos sociais também es pecíficos. Evidentemente, o prōprio delineamento desse programa e sua operacionalização impõem um conhecimento inicial considerado indispensāvel: quais problemas estão sendo pesquisados e como os pesquisadores selecionam seus problemas. 
problema como a etapa mais importante do processo da pesquisa, infere-se que o seu conhecimento e escolha são etapas extremamente valiosas, não somente para os pesquisadores, mas, também, para os prōprios administradores de pesquisa.

$$
\text { A esse respeito Busch e Lacy (1983) em estudo }
$$
pionei ro sobre pesquisadores agrícolas dos Estados Unidos, mostraram que o processo de escolha dos seus problemas de pesquisa estão assentados em contextos pessoais, interpessoais, organizacionais e interorganizacionais.

Em verdade tem-se verificado que a identificação de problemas de pesquisa, via de regra, tem sido atingida mediante um dos dois enfoques: o enfoque do problema em si e o enfoque da escolha do problema.

Busch e Lacy (1983) consideraram que o enfoque do problema tende a ser elaborado a partir de compromissos teóricos dos pesquisadores e segundo a perspectiva das especialidades científicas onde a teoria, seus conceitos associados e a tendência à compartimentalização do conhecimento científico determinada pelas especialidades. podem "direcionar a atenção longe de uma problemätica inteira.

Já o enfoque da escolha dos problemas é abordado por Merton (1973), a partir de critérios internos ao processo social da ciência. Trata-se, portanto, de critérios 
desenvolvidos empiricamente em um estudo realizado com uma lista de 21 desses critērios, distribuidos entre diretrizes administrativas, vocação pessoal, recompensas institucionais, motivação política e influências de organizações. Esse estudo revelou uma tendência muito forte de os cientistas adotarem, na escolha de problemas, critērios paradigmäticos. Essa tendência permite inferir que critērios extra-científicos constituem pontos de referência para os cientistas.

Tais considerações remetem à seguinte questão: Será que o purismo, o cientificismo e o paradigmatismo, inerente ao cientista o liberam de compromissos maiores com a sociedade de que ele também é sujeito, com a própria prática social? Por outro lado, será que as tecnologias, que objetivam soluções mais práticas para problemas identificados na prātica do processo social dispensam um respaldo científico, ünica via capaz de legitimä-las?

Ainda em relação ao estudo dos problemas existentes numa unidade produtiva agrícola visando sua solução, Resende (1983), ao discutir os sistemas agro silvo pastoris considera que a melhor forma de representar as interrelações entre os componentes do sistema de uma unidade produtiva agrícola seja através do chamado tetraedro ecológico. Esse tetraedro, conforme expresso na figura a seguir, contempla quatro componentes básicos: o solo, o clima, os organismos e a socio-economia. 
$C=$ Clima

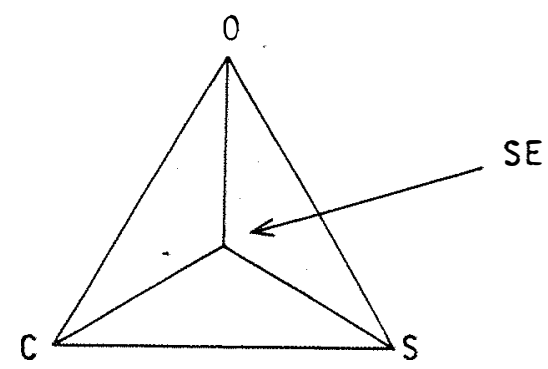

$0=$ Organismos

$S=$ Solo

$S E=$ Aspectos socio-económicos que compõem o sistema de maior interesse para o agricultor.

Assim è que, ao analisar com mais detalhes a solução dos problemas do agricultor, o pröprio Resende (1983) faz as seguintes observações: "a solução de problemas não ë feita num vazio. Ela é feita um contexto que envolve, no sistema que estamos considerando, o tetraedro ecológico expressado na figura acima: Clima-Solo-Organismos-Homem (sōcio-economia). Não hä sentido final, sob o ponto de vista de solução, de examinar-se os problemas fora deste contexto. Assim ë que as decisões, para serem tomadas com sabedoria têm que ser inseridas (e bem) no contexto sócio-economico que envolve e ajuda a caracterizar o sistema. Pequenos e grandes agricultores, sob as mesmas condições de solo, clima e organismos estão formando sistemas muito diferentes". 


\section{Difusão de Tecnologia}

As idēias discutidas anteriormente parecem ter deixado claro que a interdisciplinaridade constitui a pedra angular do modelo de pesquisa proposto pela EMBRAPA. Assim sendo e considerando que a atividade de Difusão de Tecnologia, pela sua dinâmica e característica, só dará sementes fecundas no momento em que a idéia de interdisciplinaridade estiver sendo operacionalizada por grande parte dos pesquisadores do Centro Nacional de Pesquisa de Milho e Sorgo, chegou-se à conclusão de que esses elementos teöricos que fundamentam toda a filosofia de trabalho da EMBRAPA, quais sejam a "Interdisciplinaridade" (enquanto objetivo operacional da pesquisa) e "Sistema de Produção" (enquanto instrumento de transferência de tecnologia e acessório metodológico para a compreensão plena da interdisciplinaridade), deveriam constituir uma das preocupações centrais do trabalho de Coordenação de Difusão de Tecnologia. Partiu-se, para isto, da compreensão de que, sem interdisciplinaridade, Difusão de Tecnologia seria uma falācia, algo desvinculado da tarefa do pesquisador; um aleijão dentro da Unidade de Pesquisa. Na verdade, uma das tarefas mais importantes a ser cumprida pela Coordenação da Difusão de Tecnologia é o esforço junto à equipe de que faz parte essencial - no sentido de ampliar a aplicação prätica do conceito de interdisciplinaridade. E uma das formas mais eficientes para se atingir esssa perspectiva é propor para cada pesquisador, uma metodologia de Difusão de 


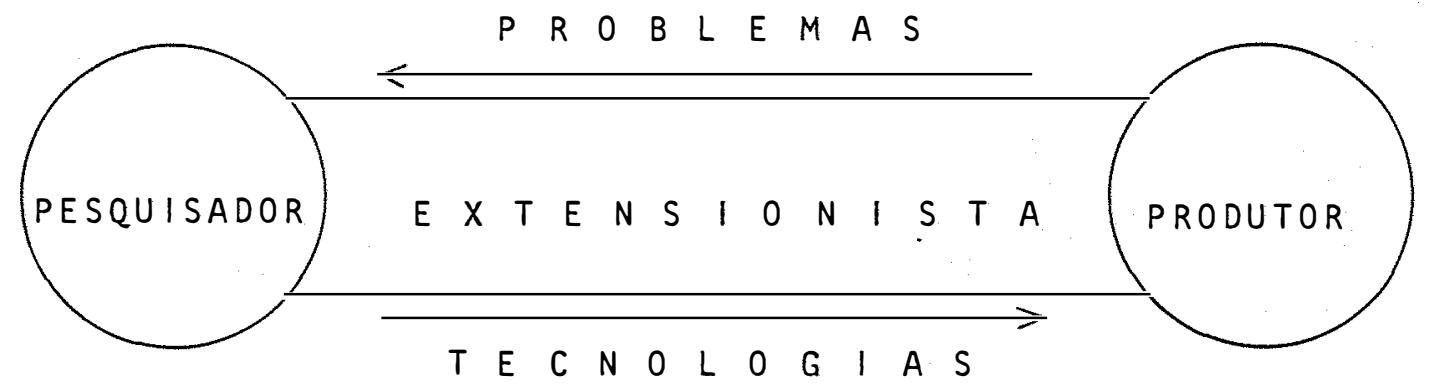

"Observando bem a representação, percebe-se que o produtor, usuārio natural de todo o conhecimento gerado em termos de tecnologia, nunca ou muito dificilmente tinha oportunidade de manter um contato mais estreito com o pesquisador" (Schaun, 1976). Na verdade, pretendia-se com esse esquema que o extensionista agisse como uma "ponte"no processo, captando, junto ao agricultor, os principais problemas de produção e transferindo esses problemas para o àmbito da pesouisa, na expectativa de que eles viessem a constituir, na ótica do pesquisador, projetos de pesquísa. Dentro dessa mesma perspectiva o extensionista deveria absorver todos os resultados de pesquisa alcançados nas diversas instituições a eles dedicados e transferir esses resultados em forma de tecnologia agronómica para os produtores. Analisando-se, portanto, a representação gräfica à luz dos objetivos acima estabelecidos pelo Sistema ABCAR, podemos perfeitamente inferir: se, por um lado, a interpretação feita pelo extensionista dos problemas identificados na fazenda do produtor não era a mesma interpretação que seria estabelecida pelo pesquisador, se ele pessoalmente observasse o problema "in loco", por outro lado, o esquema proposto denota a forte tendência do pröprio exten- 
Tecnologia que seja adequada às características da tecnologia em si. E essa metodologia precisa ser suficientemente abrangente para atingir todas as fases da atividade da pesquisa, fazendo parte indispensāvel, portanto, da atividade de pesquisa enquanto processo.

Isto porque, a difusão de qualquer tecnologia do Centro Nacional de Pesquisa de Milho e Sorgo, deverá contar com a participação de quem a gera, no caso o pesquisador.

Ora, se se considerar que a Difusão de Tecnologia, examinada aqui conceitualmente como um processo, e que, portanto, deve manifestar-se em todas as fases que compõem a atividade de pesquisa (identificação do problema, geração e transferência da tecnologia), é de suma importância compreender-se o carāter essencialmente dinâmico de que esse conceito se reveste. E isto se reforça quando se considera o fato de que a EMBRAPA propõe um modelo de Geração de Tecnologia cujo processo deve iniciar-se no conhecimento da realidade do produtor por parte do pesquisador e se encerrar no momento em que o próprio produtor estiver utilizando os seus resultados.

Assim sendo, é necessārio analisar-se o Sistema de Assistência Técnica ao produtor agrícola brasileiro proposto e desenvolvido durante muito tempo pelo antigo Sistema ABCAR (Associação Brasileira de Crédito e Assistência Rural) e simbolizado pelo seguinte modelo: 
sionista ser a barreira a dificultar o contato direto entre o pesquisador e o produtor. Esses dois aspectos reforçam a idéia de que, dificilmente, um problema visto pelo extensionista, interpretado pelo extensionista, à luz, portanto, da sua metodologia de trabalho e, principalmente, da ötica com que ele observa e interpreta os problemas da natureza, poderia constituir estímulo suficiente para o pesquisador, com todas aquelas características, principalmente de monodisciplinaridade jä abordados anteriormente, incorporä-lo como uma idéia. välida e, portanto, passível de ser transformada num projeto de pesquisa. Assim sendo, passamos a ter, em realidade, dois mundos diferentes: - o do pesquisador e o do extensionista. Aquele, sem conhecer em profundidade os verdadeiros e reais problemas do produtor, buscando, portanto, fontes de inspiração para pesquisar em àreas que, via de regra, não coincidiam com a realidade produtiva, gerando, em consequéncia, conhecimentos que não deixavam de ter validade e rigor cientifico, mas que nem sempre interessavam ao seu usuärio natural, o produtor. Por tais razões, impossibilitado de transferir tais tecnologias para o produtor. Hä, evidentemente, uma série de outros fatores, principalmente de natureza psicolögica, histörica e ideolögica, que contribuiram para reforçar esse quadro e que, naturalmente, já constituem elementos de preocupação para outros estudos futuros. Pretende-se, todavia, no momento, apenas abordar as questōes acima, por se considerar suficientes para estabelecer uma anälise comparativa entre a 
perspectiva estabelecida pelo Sistema ABCAR (Associação Brasileira de Crédito e Assistência Rural) e o modelo proposto pela EMBRAPA. 0 aparecimento da EMBRATER, convergiu profundamente com o modelo proposto a seguir, em que os sistemas de Pesquisa e Extensão Rural, alēm da Produção, devem compor um mesmo processo.

Assim, tomemos o esquema gräfico a seguir, como a simbolização da proposta teörica estabelecida pela EMBRAPA como um modelo dinâmico de geração e transferência de tecnologias úteis para os produtores agrícolas brasileiros:

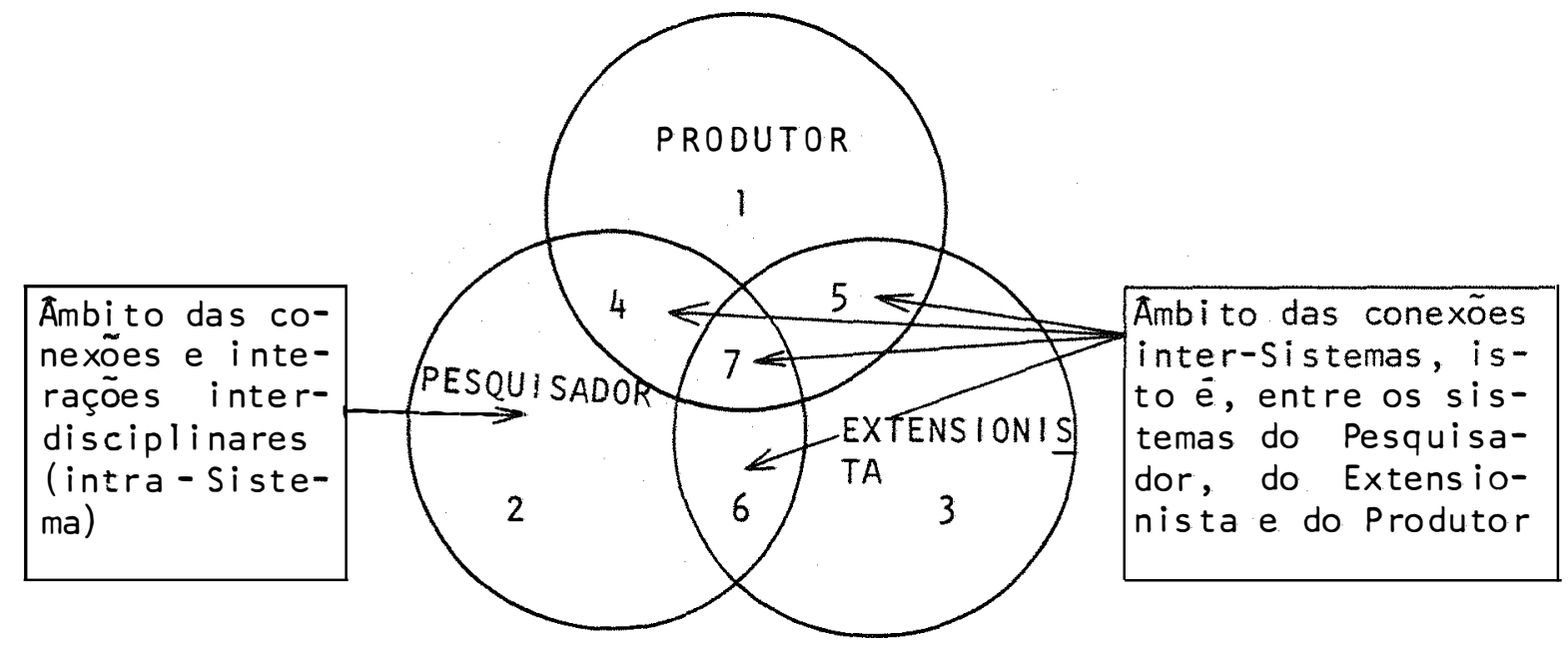

A observação do esquema gräfico nos mostra, segundo Schaun (1976):

1. A àrea específica de ação do produtor: a ārea das suas decisões pessoais na condução e administração do seu negö- 
cio, a sua atividade mais de execução da atividade produtiva.

2. A àrea específica de ação do pesquisador: o momento ou a fase da geração do conhecimento elou tecnologia.

3. A àrea específica do extensionista: a fase de planejamento da sua ação e, principalmente, a montagem da estratégia e metodologia de trabalho, elaboração de projetos etc.

4. A àrea comum entre pesquisador e produtor, para enriquecimento do processo, principalmente através da retroalimentação ao pesquisador.

5. A àrea comum entre extensionistas e produtores, na fase de orientação direta e aplicação, no campo, de toda a estratégia montada pela Assistência Técnica para a transferência ao produtor, das tecnologias agrícolas capazes de contribuir efetivamente para o aumento da produção e produtividade.

6. A àrea comum de envolvimento do pesquisador e extensionista, onde vemos, principalmente, a oportunidade de aumento do estoque de conhecimento técnico-cientifico do extensionista e conhecimento, pelo pesquisador, de como está sendo transferida a tecnologia para o produtor.

7. Finalmente, a àrea que envolve os três elementos, principalmente nos momentos de discussão e anälise dos problemas reais da produção, para que se possa assim, estabelecer bases seguras para a montagem do Sistema de Produção, que só serão viāveis com a participação de todos. 
Esta proposta de um modelo Interdisciplinar de pesquisa, estabelecido pela EMBRAPA, na qual a Difusão de Tecnologia deve participar decisivamente com propostas de metodologias capazes de contribuir efetivamente para viabilizar e facilitar o contato e o processo de comunicação entre os Produtores, Extensionistas e Pesquisadores é uma questão indiscutível. Além disso, se atendida essa perspectiva da EMBRAPA, pode-se estar contribuindo para evitar, até certo ponto, o problema mencionado anteriormente por Frank.

Retome-se agora, os dois seguintes pontos:

Em primeiro lugar a partir da anälise dos conceitos de Modernização e Desenvolvimento, estabelecidos por Jaguaribe (1978) percebe-se que a modernização pode ser alcançada e não contribuir efetivamente para o processo de Desenvolvimento, pois que, para que este ocorra, è necessärio que os efeitos privilegiantes da modernização incorporem indispensavelmente as variāveis participativas e direcionais de um sistema social. Aliàs, esta é uma referência teōrica capaz de fundamentar suficientemente determinados fenómenos empiricos que serão abordados adiante e que estão relacionados di retamente com a pesquisa feita especialmente para atender às perspectivas do presente estudo. Trata-se, portanto, do trabalho feito utilizando-se o "Milho Piranão" como uma tecnologia moderna, junto a produtores de milho do Estado de São Paulo. 
Tecnologia, para se desenvolver em plenitude, impõe um certo compromisso do Pesquisador, pelo menos na compreensão de que a geração de uma tecnologia deve ter o seu embrião num profundo contato inter-sistemas (Pesquisador $x$ Produtor), para que se possa, através desse contato, identificar problemas que realmente estejam interferindo no Sistema de Produção e na verdadeira realidade produtiva. A geração de uma tecnologia que partiu de um problema imaginado pode conduzir a uma perspectiva abstrata e suficientemente distante da realidade de fato, o necessário para não despertar, na fase da sua adoção pelo produtor, o interesse esperado.

Em verdade, quando se propõe, como uma das diretrizes básicas da difusão de tecnologia na Unidade de Pesquisa o uso do "Sistema" como um reforço metodológico à propria prática da pesquisa na geração de tecnologia torna-se imperiosa a compreensão de que o carăter interdisciplinar objetivo operacional da pesquisa proposto pela EMBRAPA - e o conceito de Sistema estão de tal forma conectados que às vezes se torna difícil estabelecer com necessária clareza onde se localizam os limites conceituais dessas duas perspectivas.

Dessa forma, pretende-se, ao se pensar no estudo e pesquisa do Milho, identificar os mecanismos de conexão existentes entre as diversas disciplinas que compõem o sistema físico da produção do milho. 
Nesse ponto, as conexões mais evidentes se estabelecem dentro desse sistema, a cujas conexões podemos chamar de conexões intra-sistema, isto ë, dentro do sistema de produção do milho. Essas conexões e interações ocorrem, bäsi camente, nas fronteiras, e proximidades existentes entre, por exemplo, o solo, a semente, a mecanização, os tratos culturais, a fertilidade, as pragas, as doenças, o mercado, o transporte, etc. Que essas interações existem, é um fato inquestionável, e o exemplo jà citado anteriormente relacionado com a pesquisa em desenvolvimento no Centro Nacional de Pesquisa de Milho e Sorgo, sobre o controle de pragas de grãos armazenados, bem pode i lusträ-lo. o que se propõe, então, é o esforço dos pesquisadores especialistas nessas diversas äreas, identificarem os limites disciplinares entre elas, suas proximidades, suas distäncias, enfim, a forma como essas interações ocorrem e se manifestam.

Nesse momento pretende-se que as interações se manifestem e se exerçam intra-sistema, isto é, dentro do sistema de pesquisa, onde os pesquisadores são os seus componentes principais. Nesse grau, Jaguaribe (1975), confirma que é característico de sistema de interação humana, quaisquer que sejam suas dimensões, grau de complexidade e regime interno, a existência de: "(1) uma pluralidade de atores (2) interagindo para realizar objetivos (3) por certos meios e (4) em certas condições". E Japiassu (1976) ao se referir às motivações que contribuem para conduzir, esses "atores", que são os 
pesquisadores, cita como principais: o "conjunto das necessidades intelectuais e afetivas bem como dos interesses que de um modo ou de outro podem levar os pesquisadores a se engajarem no empreendimento interdisciplinar". Aqui então parece residir um dos pontos centrais do esforço da difusão de tecnologia na unidade de pesquisa, no momento em que convida e propõe a profunda reflexão da equipe sobre essa perspectiva interdisciplinar. Afinal de contas, essa não tem sido uma tarefa muito fäcil, exatamente porque, via de regra, não se tem identificado uma convergência estimulante entre essas necessidades intelectuais e afetivas, no plano mais subjetivo e os graus de interesse no plano mais objetivo em relação às diretrizes da pesquisa.

Por outro lado, hä que se reconhecer a necessidade de identificação das interações que existem e a forma como elas se manifestam, entre os Sistemas do Pesquisador, do Extensionista e do Produtor. Afinal de contas, esses já se apresentam como componentes de um sistema maior que é o processo da produção agrícola como um todo, do qual participam Produtores, Extensionistas e Pesquisadores. Ao se considerar välida essa perspectiva, não se pode prescindir do reconhecimento de que é extremamente importante e necessäria a identificação, tambēm, das interações que existem entre os sistemas do Produtor, do Extensionista e do Pesquisador, porque, acredita-se, a não identificação dessas interações pode comprometer, muitas vezes, não apenas a realização de um projeto de 
pesquisa, mas até mesmo todo o processo da produção do produto em foco, no caso presente, o milho.

Apenas para ilustrar essa preocupação, identifique-se a seguinte evidência: dentro do Sistema de Pesquisa para geração de tecnologia, existe uma etapa, indispensável, e naturalmente a mais importante. Trata-se da IDENTIFICAÇÃO DO PROBLEMA. Ora, o estabelecimento de um problema que se vai configurar num projeto de pesquisa e que tenha sido identificado a partir de simples analogias ou mesmo de imaginações abstratas e subjetivas, nem sempre resultará num projeto que, concluido, pos $a$ oferecer alternativas de soluções objetivas para os produtores agrícolas. A não ser por mera coincidência. Dessa forma é que se pode considerar o fato inquestionável de que um projeto de pesquisa que tenha sido estabelecido a partir de um conhecimento da realidade produtiva de fato e cujo conhecimento passe a ser a principal fonte de inspiração a alimentar o pesquisador na identificação de problemas verdadei ramente objetivos, levará a resultados que ganham uma probalidade de adoção por parte dos produtores, consideravelmente maior. Todavia, para que essa perspectiva possa ser alcançada em plenitude, è indispensável o contato direto, principalmente no campo, entre pesquisadores e produtores. Esse contato, evidentemente, deverá remeter ao conhecimento da realidade de fato e não da realidade aparente, que, muitas vezes, por ter sido essa adotada, tem conduzido, também, a muitos projetos que, se não perdem em fidedignidade e valida- 
de, comprometem consideravelmente a objetividade. Dentro dessa perspectiva e nessa fase crucial do projeto de pesquisa, que é a identificação do problema, a Difusão de Tecnologia se reveste de uma importância muito grande no momento em que, participando juntamente com os pesquisadores da ärea biolögica, pode dar excelentes contribuições, atravēs de instrumental metodolögico para respaldar cientificamente a identificação desses problemas, principalmente os de natureza sócio- económica. Por outro lado, as contribuições da Difusão de Tecnologia são muito üteis na intepretação de tais problemas, contribuindo para a definição do grau de objetividade de cada um deles e para estabelecer sua prioridade correta. Estas é que constituem as bases, as raízes, para a definição das diretrizes da pesquisa no seu àmbito mais abrangente, mais objetivo, institucional mesmo, e os embriões para a maior objetividade dos projetos de pesquisa.

Assim è que a identificação das conexões entre os sistemas do Produtor, do Extensionista e do Pesquisador, a que se pode chamar de conexões inter sistemas constitui, tambēm, uma das preocupações do Centro Nacional de Pesquisa de Milho e Sorgo, sem o que os seus objetivos operacionais não serão atingidos. Retomando portanto a questão o Milho Piranão e o objetivo estabelecido para este estudo, pode-se formular a seguinte questão: Por que, sendo o Milho Piranão considerado como uma inovação tecnológica ūtil, não tem sido utilizado em larga escala pelos Produtores de Milho? 
111. METODOLOGIA

1. Area do Estudo

A pesquisa que forneceu os dados capazes de confirmar empiricamente o presente estudo, foi realizado na micro-região homogênea Serra de Jaboticabal (Censo Agropecuário - S.Paulo F. IBGE 1970).

Essa região envolve os municípios de Bebedouro, Cândido Rodrigues, Fernando Prestes, Guariba, Jaboticabal, Monte Alto, Monte Azul Paulista, Pi rangi, Pitangueiras, Santa Ernestina, Taiaçu, Tai üva, Taguaritinga, Terra Roxa, Viradouro e Vista Alegre, no Estado de São Paulo.

Situa-se a norte do Planalto ocidental e $\vec{e}$ banhada pelas bacias dos rios Turvo e Pardo. Predomina o arenito Bauru, entretanto ocorreu, tambēm, afloramento de rochas basälticas. Dessas rochas basälticas, então, é que se originaram os solos mais ricos, principalmente nos municípios de Pitangueiras, Jaboticabal, Viradouro e Terra Roxa, a leste 
dessa micro-região.

o clima é quente e os invernos são secos, com a ocorrência, a oeste e sul da micro-região, de campos e cerrados com vegetação rala. A precipitação pluviométrica anual está entre 1400 e $1500 \mathrm{~mm}$, e a altitude varia entre 500 e 800 metros acima do nível do mar.

Por influência do café, principal fator de povoamento na região, a densidade demogrä́fica é considerável. A principal base de sustentação econômica é a agropecuária. Na zona leste da micro-região, onde se licalizam as melhores faixas de solos, a agricultura é bastante intensa. São expressivas, ai, as produções de café, mi lho, arroz, laranja, amendoim e algodão. Ao sul, mais especificamente em Guariba, a cana-de-açücar constitui a principal atividade agrícola e Taguaritinga encontra na produção leiteira sua maior expressão .

A região é muito bem servida por transportes, principalmente o rodoviário e o ferroviário. 


\section{Critērios de Amostragem}

Dentro da micro-região homogênea Serra de Jaboticabal, foram selecionados cinco municípios para representä-la, tendo em vista os critérios que pudessem melhor caracterizar os objetivos deste estudo que faz parte do Projeto Interdisciplinar de Pesquisa, denominado "Projeto Milho 11 ", desenvolvido por diversos departamentos da ESALQ e patrocinado pela EMBRAPA. Desta forma, era necessário que se pudesse representar os värios sistemas de produção de milho adotados na região. Bem assim, deveriam também estar representados os diversos estratos de áreas e unidades produtivas além, tambem, das diversas categorias de tecnologia agrícola. E os municípios de Jaboticabal, Pirangi, Viradouro, Pitangueiras e Taquaratinga, atendiam a esses pré-requisitos. Para sua seleção, foi solicitada ainda ao Departamento de Economia Rural da Faculdade de Ciências Agrárias e Veterinärias de Jaboticabal-UNESP, que aliās coordenou a execução de todo o trabalho de campo e aos técnicos da Divisão Regional Agrícola de Ribeirão Preto e das delegacias de Taguaritinga e Bebedouro, pertencentes a essa Divisão. Finalmente, técnicos de Casas da Agricultura da região, não somente colaboraram na seleção dos cinco municípios como acompanharam todo o trabalho de campo realizado.

Inicialmente, e a partir da convergència das indicações dos técnicos e do volume de produção, foram desta- 
cados os seguintes municípios: Jaboticabal, Pirangi, Viradouro, Terra Roxa, Pitangueiras e Taquaritinga. Considerando que Terra Roxa e Viradouro apresentavam características mais semelhantes no que se refere às condições da cultura do milho, descartou-se Terra Roxa da pesquisa, pelo fato de esse município estar localizado a uma distância muito grande de Jaboticabal, selecionada para ser a base das operações de coleta de dados.

Todos os produtores de milho dos cinco municípios selecionados compunham, teōricamente o universo da pesquisa. Tratava-se portanto de um universo praticamente desconhecido, jā que não se poderia precisar quantos eram, que características apresentavam esses produtores e como se distribuiam na àrea.

Tratou-se inicialmente de coletar o maior nümero possível de informações acerca desse universo. Assim, os municípios foram percorridos procurando-se contato com os agrônomos e técnicos fas Casas de Agricultura bem como com outras pessoas indicadas como conhecedoras das características da agricultura na região. Não havia consenso quanto a um nümero provāvel de produtores de milho, as opiniões indicavam variações sensíveis quanto ao nível de tecnologia empregado na cultura do milho, e, eram unânimes quanto à jä inexistência de algumas categorias, bem como pequeno nümero de agricultores em outras das categorias pretendidas para o estudo. Tor- 
nava-se impossível a determinação de uma amostra aleatōria representativa do universo e que ao mesmo tempo atendesse às exigências do projeto mi lho que determinavam a necessidade da presença de observações em cada uma das diferentes categorias em nümero suficiente para anälise.

Desta forma, um levantamento de dados, sobre produtores de milho que haviam comprado sementes para o ano agricola 77/78, junto às Casas de Agricultura e firmas vendedoras de sementes de milho, possibilitou o trabalho de localização desses produres nos mapas dos municípios (unidades de pesquisa), a partir do que se pode verificar a distribuição dos mesmos pela ärea, o que ocorria de forma dispersa. Como os agricultores compradores de sementes representavam seguramente nümero menor que o total de plantadores de milho, e estes por sua vez representavam igualmente nümero menor que o do total dos agricultores, optou-se pelo procedimento seguinte :

1. De acordo com o mapa assinalado com os compradores de sementes, procurou-se identificar os produtores de milho da àrea percorrendo-a até alcançar um nümero de $10 \%$ da totalidade dos agricultores. Isso certamente daria uma fração de amostra maior que $10 \%$ entre os produtores de milho.

2. Ao correr dos trabalhos de campo, verificou-se que em Viradouro e em Pitangueiras as informações interessantes para o projeto do milho eram mais ricas que as 
de Taquaritinga, onde o milho à atividade secundāria e os agricultores apresentavam muita resistência para informar ao entrevistador. Tambēm, o município é muito grande e comprido e os produtores estão espalhados em todo o territōrio municipal. Por isso, aumentou-se os casos em Viradouro e Pitangueiras e diminuiu-se em Taguaritinga. Assim, como estes dois municípios, pirangi também apresenta maior nümero de casos de agricultores de "lavoura", isto é, com culturas de subsistência, o que era altamente interessante para o projeto. Aumentou-se o número de casos neste município tambēm.

3. Finalmente, procurou-se entrevistar, também, todos os produtores de sementes de milho na ärea, com vistas aos contrastes nos sistemas de produção.

Em suma, a amostra foi intencional, com vistas aos objetivos do projeto milho. Entretanto, em relação aos dados do IEA referentesà previsão de safra na região constatou-se, "a posteriori", que nada menos que $50 \%$ da safra de milho da região foi proveniente dos produtores entrevistados para a pesquisa.

Coerentemente, hä casos suficientes para anälises, com vistas aos diferentes sistemas de produção utilizados pelos produtores da região. Há também representantes de todas as categorias de unidades produtivas da região. os prëempresärios, possivelmente, foram entrevistados em sua quase totalidade, dado o seu pequeno nümero e à tendência ao seu 
desaparecimento da região. Entre eles predominam os não proprietärios, explorando terras de outrem em parceria ou arrendamento. Outras formas pré-capitalistas de tenēncia praticamente jà desapareceram da ärea. Houve, tambēm, possibilidade de se coletar informaçōes sobre o nível de tecnologia corrente na ärea. Com isso, acredita-se que a amostra seja suficiente para as finalidades do estudo. 
3. Obtenção dos Dados

Do total de 251 produtores de milho (considerou-se produtor de milho aquele que houvesse cultivado milho nos três ültimos anos) foram relacionados aleatoriamente 151 produtores e, com eles, foram feitos três levantamentos: o primeiro em julho de 1978 (questionärio anexo 1); o segundo em janeiro de 1979 (questionärio anexo 11); o terceiro, realizado em julho de 1979 , apōs a colheita do milho, que forneceu dados relativos a rendimentos alcançados (questionário anexo $(11)$. Ao final do terceiro levantamento, selecionaramse os produtores que responderam aos 3 questionários e, apenas com esses, e que somavam 148, passaram a ser analisados os dados de informações obtidos. Em julho de 1980, um ano após a colheita, foi ti rada uma sub-amostra de 50 produtores, dentre os 148 que participaram dos 3 levantamentos anteriores e, com esses, foi feito um quarto levantamento (questionärio IV).

o primeiro questionärio (anexo 1) objetivou identificar se o produtor realmente tinha alguma tradição no cultivo do milho e, tambëm, se ele já conhecia ou, pelo menos, se tinha alguma vez ouvido falar sobre o "milho PIRANÃo". Concluida a tomada de informações acima referidas, foi entregue a cada um dos 151 produtores um pacote contendo $1 \mathrm{Kg}$ de sementes de milho Piranão, que nos foi fornecido pelo Departamento de Genética da ESALQ (Escola Superior de Agricultura 
Luiz de Queiroz, de Piracicaba - SP). Nesse momento, o produtor foi orientado no sentido de plantar aquelas sementes na mesma época em que fosse plantar o milho tradicionalmente utilizado. Pediu-se ainda que ele observasse o milho piranão durante todo o seu ciclo, principalmente até a fase de pendoamento e espigamento, que é a fase em que o material manifesta as suas características botānicas e vegetativas com maior evidência. Pretendeu-se com isto, atingir dois objetivos: em primeiro lugar, identificar se o produtor iria estabelecer alguma forma de comparação entre o material tradicionalmente utilizado por ele e o milho Piranão. Em segundo lugar, identificar se as observaçōes feitas pelos produtores sobre as características do milho Pi ranão coincidiam com as características jä anteriormente estabelecidas pelos pesquisadores que geraram essa tecnologia. Isto poderia, com a devida segurança empírica, identificar não somente a acuidade do produtor na observação de um material novo, como a confiabilidade que se poderia dar às outras informações subsequentes do produtor. Haja vista que as características botânicas e morfológicas do milho Piranão jà haviam sido estabelecidas pela pesquisa e jä eram conhecidas por nós, através da revisão de literatura sobre o Piranão, incluida no projeto de pesquisa.

Ainda foi dito ao produtor, no momento da entrega das sementes, que as informações que ele pudesse oferecer sobre aquele material seriam de grande importância, pois 
se tratava de um tipo de milho ainda pouco conhecido pelos produtores e a eles é que, verdadeiramente, se destinava.

Estava sendo iniciado, assim, o teste de um mecanismo de Difusão de Tecnologia, qual seja, o de oferecer a tecnologia a ser difundida ao seu usuário natural, o produtor, e identificar o tipo de interesse que aquela tecnologia pode despertar.

Hä ainda a considerar o seguinte: alēm do tempo transcorrido entre a entrega das sementes ao produtor (mês de agosto), e a época de plantio (2a. quinzena de outubro à la. quinzena de novembrol ser relativamente longo, acresce-se o fato de ter sido muito pequeno o tamanho da amostra recebida pelo produtor (apenas $1 \mathrm{~kg}$ de sementes). Esses dois fatores poderiam determinar uma baixa frequência de produtores que seriam levados a plantar o milho: o longo tempo entre o recebimento da semente e a época de plantio, poderia levä-los ao esquecimento, o que seria reforçado com o pequeno pacote de sementes, capaz, portanto, de ser guardado até no fundo de uma gaveta e, alí, esquecido. As experiências de avaliar, dentro do sistema do produtor, as tecnologias geradas na unidade de pesquisa, realizadas por Pesquisadores do CNPMS têm indicado que a àrea ideal para esse tipo de observação deve variar entre um quarto de hectare em unidades produtivas de subsistência e um hectare em unidades de produção comercial onde se usa intensa mecanização. Esses limites mínimos de 
äreas de observação e avaliação de tecnologia demandam um consumo entre $5 \mathrm{Kg}$ e $20 \mathrm{Kg}$ de sementes respectivamente.

o segundo questionärio, aplicado exatamente na época do pendoamento e espigamento do milho, objetivou, como se pode identificar através do anexo 11 , em primeiro lugar, identificar a frequência de produtores que plantou as sementes do milho Piranão e, em segundo lugar, identificar, além das observações comparativas que estavam sendo feitas entre o Piranão e o milho tradicionalmente plantado, quais as características do Piranão que eram identificadas pelo produtor.

o terceiro levantamento, feito jä após a colheita total do milho, objetivou levantar, junto aos produtores, aspectos do milho Piranão relacionados com rendimento físico do milho, empalhamento da espiga, tombamento da espiga, tombamento ou acamamento, alēm de incidência de pragas, principalmente traças e carunchos que são as mais incidentes nos milhos armazenados em paiol. Ainda se procurou nesse levantamento, identificar se o produtor já manifestava alguma atitude em relação à adoção ou não dessa tecnologia.

o quarto levantamento foi realizado 1 ano após encerrada a pesquisa e, como referido anteriormente, foi feito com uma sub-amostra de 50 produtores, retirada aleatoriamente entre os que foram envolvidos na pesquisa que participaram dos 3 levantamentos. Esse levantamento, questionário anexo IV, objetivou identificar a opinião final dos produto- 
res em relação ao milho PIRANÃo e quais os fatores que os teriam levado a adotar ou rejeitar o milho piranão como uma tecnologia moderna alternativa.

Alëm dos levantamentos feitos em campo, junto aos produtores, tambëm foi feita uma entrevista com os pesquisadores que trabalharam na geração do milho piranão como uma tecnologia moderna. Buscou-se, nestas entrevistas, atingir dois objetivos bäsicos: em primeiro lugar, identificar quais os critérios adotados pelos pesquisadores para escolher o milho Piranão como um projeto de pesquisa a ser desenvolvido e quais os objetivos bāsicos desse projeto. Em segundo lugar, tentar identificar quais os mecanismos utilizados pelos pesquisadores para fazer com que o milho Piranão, uma vez gerado, chegasse até seu usuärio natural, o produtor. Vale adiantar que essa entrevista não foi sistematizada atravēs de um questionärio previamente elaborado. Foi uma entrevista feita diretamente pelo autor do presente estudo junto aos pesquisadores e ela se limitou a levantar apenas os dois pontos abordados acima (critērios de escolha e mecanismo de difusão), a partir do que foram feitas as anotações das respostas dadas, que serão discutidas, naturalmente, em outro ítem do presente estudo. 
4. Informação Adicional Sobre os Municípios Estudados

$$
\text { Uma anälise mais detalhada das Tabelas } 3,4 \text { e }
$$
5, onde as unidades produtivas têm sua àrea total concentrada na faixa de 0 a 100 ha, o que caracteriza a produção agrícola concentrada em pequenas e médias propriedades, os produtores, na sua grande maioria são proprietários, pré-requisito quase indispensāvel para obtenção de crēdito rural - ítem hoje considerado indispensável no processo de produção agrícola, pode-se inferir que a ärea apresenta uma vocação agrícola indiscutível. 
.70.

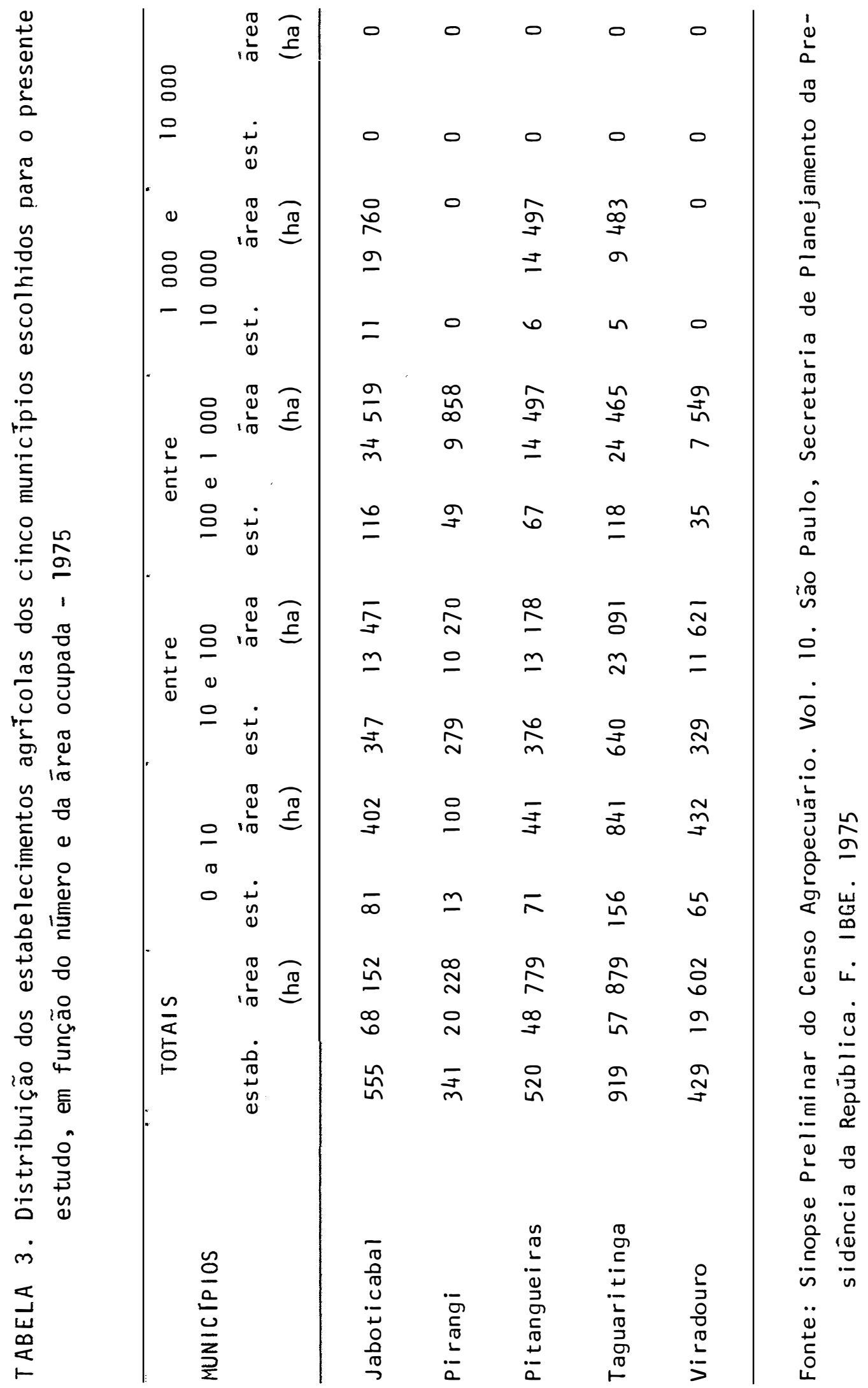


Jaboticabal - $77 \%$ das unidades produtivas têm ärea total entre 0 e 100 ha e isto representa $20 \%$ da ärea total das unidades produtivas agrícolas do município.

Por outro lado, o estrato contido na faixa de àrea total entre 100 e 1.000 , e que representa $20 \%$ do nümero total de unidades produtivas, detềm $50,6 \%$ da àrea total das unidades produtivas agrícolas do município.

Pirangi $\quad-85,6 \%$ das unidades produtivas têm ärea total entre 0 e 100 ha, representando $51,26 \%$ da ärea total das unidades produtivas agrícolas. Ao lado disto, o estrato contido na faixa de 100 a 1.000 ha, que representam $14 \%$ do total, detém 49\% da àrea total das unidades produtivas agrícolas do município.

Pitangueiras - $86 \%$ das unidades produtivas têm ärea total entre 0 e 100 ha detendo $30 \%$ da àrea total das unidades produtivas, enquanto o estrato contido na faixa de 100 a 1.000 ha representam $13 \%$ do nümero de unidades produtivas, detendo $30 \%$ da ärea total das unidades produtivas do município.

Taguaritinga - 0 município de Taguaritinga. com 796 unidades produtivas na faixa de 0 a 100 ha de ärea total, 
- que representa $87 \%$ do nümero total de unidades produtivas, detendo $41 \%$ da ärea total das unidades produtivas do município.

Por outro lado, as 118 unidades produtivas contidas no estrato de 100 a 1.000 ha representam $13 \%$ do total de unidades produtivas e detêm $42 \%$ da àrea total das unidades produtivas.

Viradouro - $92 \%$ do nümero total de unidades produtivas detêm $61 \%$ da àrea total, e estão localizadas na faixa de 0 a 100 ha, enquanto $8 \%$ das unidades produtivas detêm $38 \%$ da ärea e estão localizadas na faixa de 100 a 1.000 ha. 
.73.

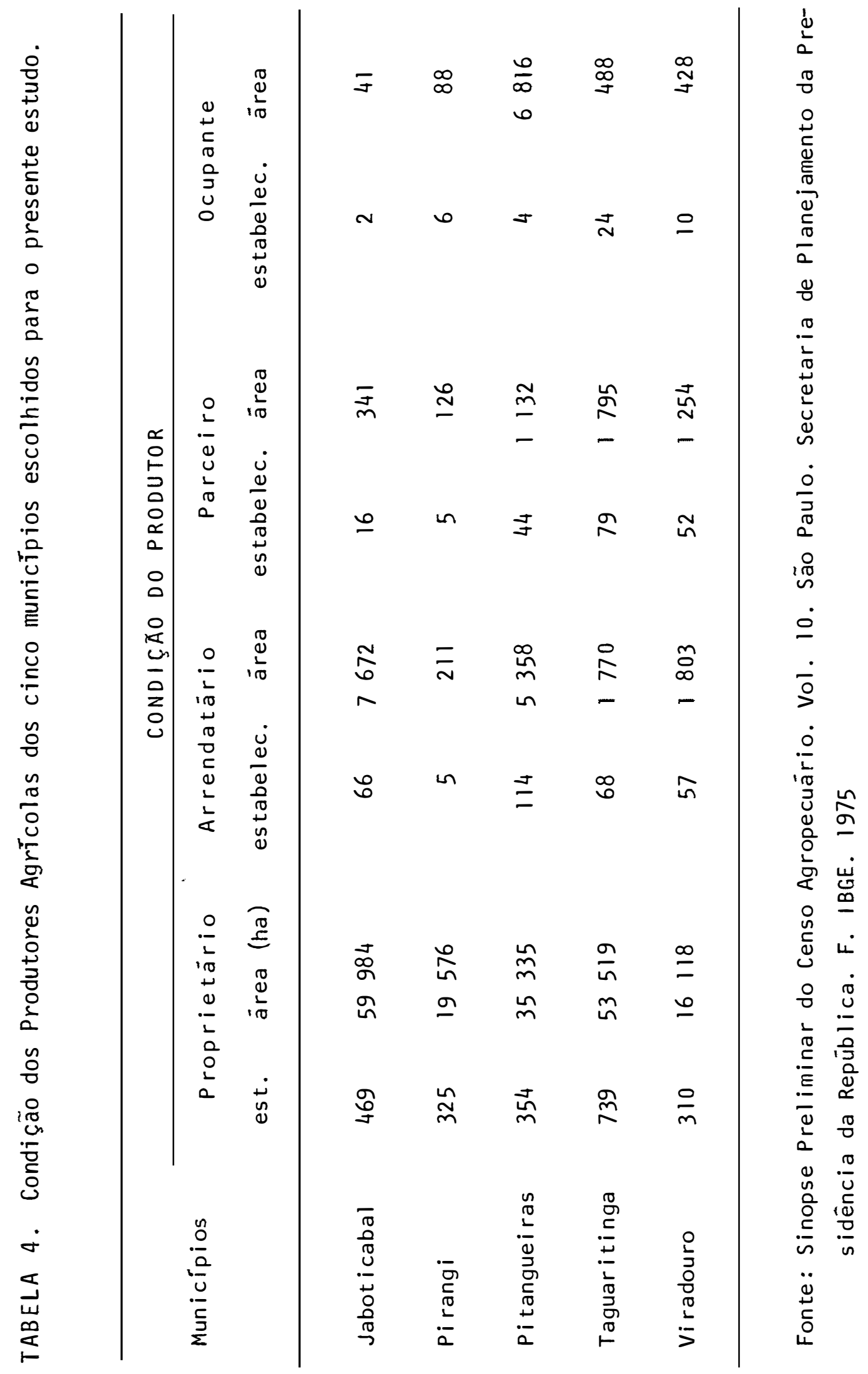


Em Jaboticabal, do total de 555 unidades produtivas, $85 \%$ dos produtores são proprietärios, $12 \%$ são arrendatärios e $3 \%$ são parceiros.

Em Pirangi, do total de 341 unidades produtivas, $96 \%$ dos produtores sião proprietārios, $1 \%$ são arrendatärios, $1 \%$ parcei ros e $2 \%$ são ocupantes.

Em Pitangueiras $70 \%$ dos produtores são proprietārios, $21 \%$ são arrendatärios, $8 \%$ são parceiros e $1 \%$ são ocupantes.

Em Taguaritinga $82 \%$ dos produtores são proprietärios, $7 \%$ são arrendatärios, $8 \%$ são parceiros e $3 \%$ são ocupantes.

Em Viradouro $73 \%$ dos produtores são proprietärios, $13 \%$ são arrendatärios, $12 \%$ são parceiros e $2 \%$ são ocupantes. 


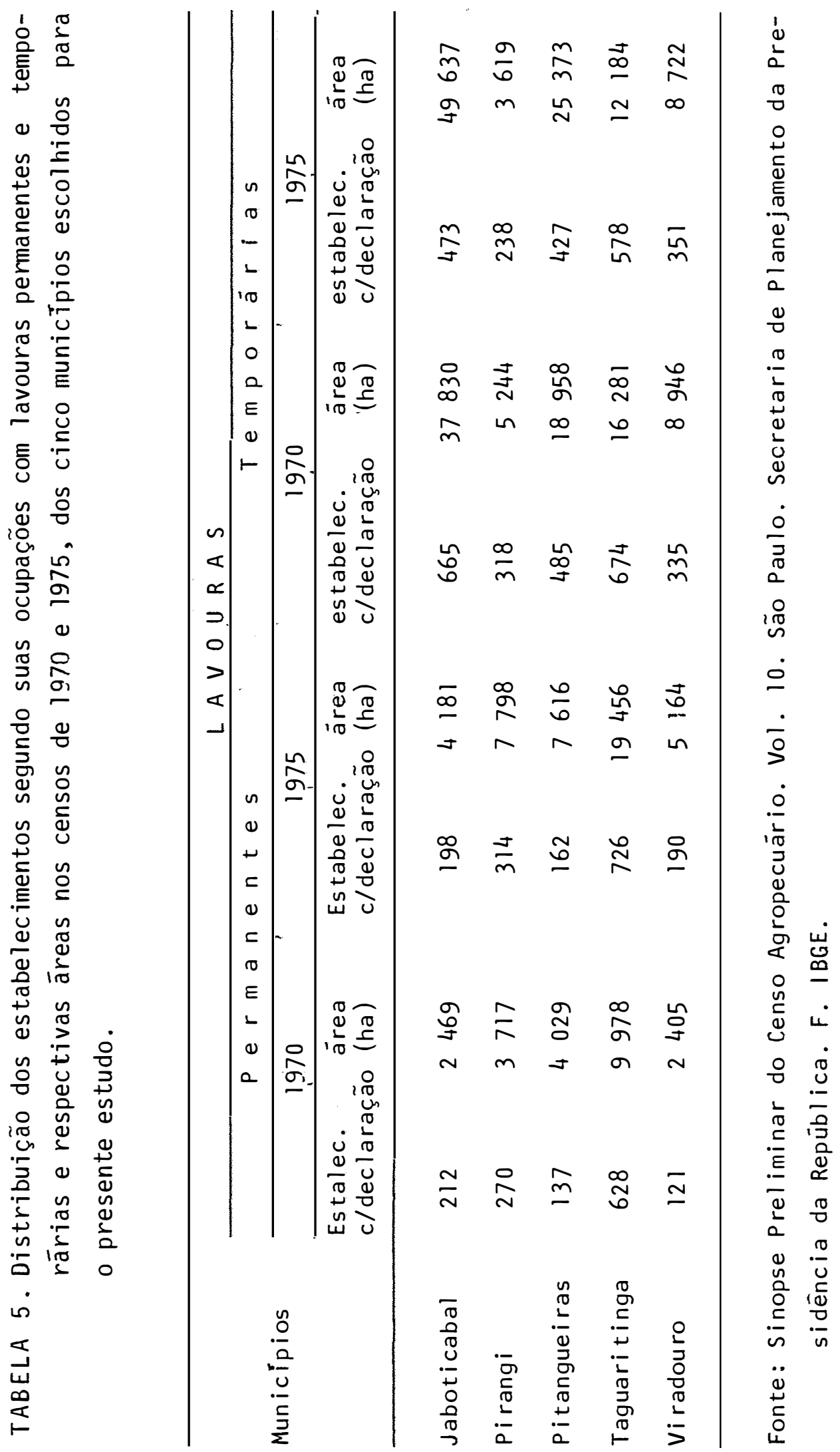


A observação da Tabela 5 indica que as lavouras permanentes têm experimentado um incremento de ärea de 1970 para 1975 ao passo que as lavouras temporärias, nesse mesmo período têm suas äreas reduzidas. Isso nos permite confirmar a tendência, que se tem observado, na região, da expansão da cultura da cana-de-açūcar. 


\section{ANALISE E DISCUSSAO DOS RESULTADOS}

1. Critérios de Tecnologias Util Adotados Pelos Pesquisadores que Trabalharam na Geração do Milho Piranão

Vale a pena discutir, antes de mais nada, os mecanismos de difusão de tecnologia adotados pelos pesquisadores que geraram essa tecnologia, a fim de se poder relacionar esses elementos com o ceticismo dos produtos em relação do milho piranão. o conceito Difusão aqui alocado já deve ser compreendido com a definição de Difusão de Tecnologia na EMBRAPA ou, mais genericamente, na Pesquisa.

Nas värias entrevistas mantidas com pesquisadores que trabalharam na geração do milho Piranão, partiu-se sempre da seguinte questão colocada de forma aberta, para que as informações pudessem ser levantadas livremente:

$$
\text { E sabido que o cientista, quando desperta a sua }
$$
mente para algum problema a pesquisar, deve assumir duas posturas que, embora não ocorram separadamente, pois elas se in- 
terpenetram e influem uma na outra, se manifestam com bastante clareza. Trata-se da postura que ele assume como cientista, onde busca alocar os recursos do conhecimento que a ciência lhe oferece para atingir seus objetivos operacionais; e da postura assumida como cidadão (como força viva e dinamica) dentro de um contexto social mais amplo de que, evidentemente, faz parte. Esta segunda postura è que lhe enriquecerà a idēia e o pensamento em busca, sobretudo, da importáncia social e económica do futuro projeto de pesquisa. Dentro desta ötica, quais as fontes de inspiração e os critērios cientifícos que o levaram a aprofundar a idéia da geração do Milho Piranão como uma tecnologia ūtil?

A partir, então, desta questão, anotaram-se as respostas e elas se repetiram da seguinte forma:

Os milhos normais são muito altos em relação aos milhos dos países adiantados que, alèm de baixos, são de alta produtividade. Ai o pesquisador está se situando numa comunidade científica internacional. No Brasil, todo o trabalho de melhoramento de milho foi dirigido para o aumento da produtividade e da resistência a pragas e doenças, mas nada foi feito para reduzir o porte. Decidiu-se por isso trabalhar nessa linha, considerando que os milhos normais, sendo de porte alto, eram muito susceptíveis ao tombamento, o que dificultava muito a prätica da colheita mecànica em vista da forte incidência de tombamento e acamamento. Os milhos altos são ideais 
para baixa tecnologia. Os milhos baixos são exigentes de alta tecnologia (mecanização). Já existe um milho aceitável para o pessoal de baixa renda, que é o milho normal. A pesquisa deve estar sempre à frente. 0 ideal è que o pesquisador procure desenvolver variedades que serão necessärias no futuro.

Retome-se, aqui, o referencial teórico nos seguintes pontos: "Interdisciplinar objetiva desenvolver, como método, a preocupação de melhor guiar a pesquisa propriamente dita. Em outros termos o que se tem em vista é a descoberta de melhores métodos para planejar e guiar a ação"... Nesse ponto é que se destaca, no processo de geração de tecnologias, a importância da objetividade na identificação do problema o que dará os elementos necessários a um bom planejamento (projeto de pesquisa) e sua operacionalização (que é a ação de pesquisar). Neste ponto é que a Difusão de Tecnologia (enquanto processo) desempenha papel relevante, pois promove o contato intra sistema e intersistemas. Considerem-se então, o sistema de pesquisa e o sistema da realidade produtiva de miIho no Brasil ou do Produtor em si. E possível, então inferir-se que as principais fontes em que o pesquisador se inspirou como aliàs está em referência expressa, foi na comunidade científica internacional e, naturalmente, na literatura das bibliotecas e das instituições de pesquisa. Ao lado disso, buscou-se identificar a realidade dos países adiantados, na expectativa de que, a prazo curto ou médio em melhor hipötese, viesse o Brasil alcançar tais parâmetros. 
Retorne-se agora aos dados das Tabelas 1 e 2:

Ao se analisar os dados dessas tabelas 1 e 2 , que refletem a realidade brasilleira em relação à produção de milho e se se retomar os dois primeiros extratos de ärea cultivada e produção, de onde se extrai que $99,5 \%$ dos produtores de milho no Brasil estão localizados na faixa de 1 a 50 ha de ärea cultivada e que esses produtores são responsāveis por $87,5 \%$ da produção brasileira de milho, e que essa categoria de produtores não utiliza a colheita mecânica, pode-se inferir que não foi a realidade da produção de milho no Brasil a principal fonte de inspiração para a geração do milho piranão.

Retomando-se ainda a idéia expressa pelo pesquisador que "o ideal é que o pesquisador procure desenvolver variedades que serão necessārias no futuro" não se questiona a importância e o valor dessas idéias mas o que se levanta é até que ponto se deve concentrar atenções em perspectivas como esta que, no âmbito da pesquisa, guarda um nível de abstração bastante elevado com relação à realidade söcio-econômica brasileira. Ainda uma observação de suma importância que se pode fazer é a seguinte: Considerando-se que o maior volume da produção do milho no Brasil é produzido por produtores de subsistência; que esses produtores não utilizam mecanização para colheita em larga escala; e que não existe nenhum fator que possa indicar a perspectiva da mudança dessa realidade, 
em prazo curto, é perfeitamente compreensível que o esforço e os recursos demandados para gerar uma tecnologia adaptada à colheita mecānica pode, na melhor hipōtese, atingir ou, em outras palavras, interessar a um contingente muito reduzido dos quase 3 milhões e duzentos mil produtores de milho do Brasil.

A Tabela 6, a seguir, extraida de um trabalho de pesquisa em terceiro ano de desenvolvimento pelo Centro Nacional de Pesquisa de Milho e Sorgo no Estado de Minas Gerais - que varia entre segundo a terceiro produtor nacional de Milho e onde se utiliza uma tecnologia de produção considerada média - bem pode ilustrar o acima exposto. 


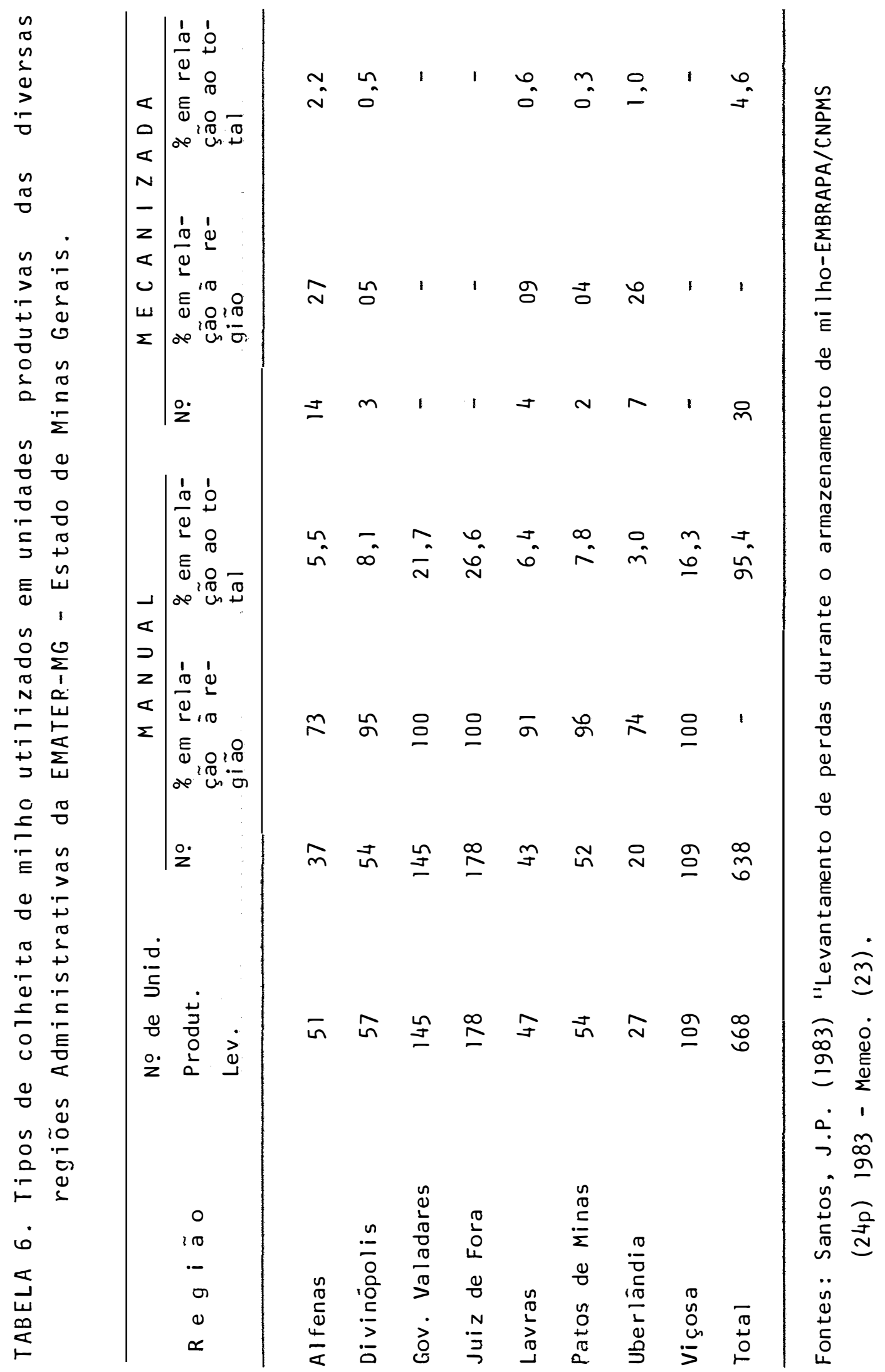


.83.

Tais questões podem, portanto, confirmar que os contatos intersistemas, isto é, entre o sistema do Pesquisador e o sistema do produtor, se exercitados de forma fecunda e sistematizada, podem constituir-se em fonte de inspiração bem mais fecunda para os problemas de pesquisa. E isto, por certo, apresentarä resultados bem diferentes dos alcançados nesta pesquisa, na fase de adoção pelo Produtor, da tecnologia gerada .

Na àrea de transferência da Tecnologia, o problema se acentuou mais, na medida em que a participação dos Extensionistas da CATI (Coordenadoria de Assistência Técnica integral), örgão encarregado, no Estado de São Paulo, de coordenar e executar os programas de Assistência Tëcnica a Produtores Agrícolas do Estado de São Paulo, não se manifestou a nível de maior comprometimento nas outras fases do processo de Pesquisa, quais sejam as fases de identificação do problema e geração da tecnologia em si. Se se considerar que a atividade de pesquisa agropecuäria envolve três fases (identificação do problema, geração de tecnologia e transferência da tecnologia) e que Produtores, Extensionistas e Pesquisadores são componentes desse processo, infere-se que eles devem participar ativa e integralmente do processo, a fim de que se possa estabelecer níveis reais de comprometimento. Ora de acordo ainda com observações e identificações junto a pesquisadores envolvidos na pesquisa do Piranão, os Produtores e Extensionistas não participaram do processo a nível de que tais com- 
promissos, se estabelecessem. Assim, as probabilidades de que tal tecnologia viesse a ser facilmente adotada em larga escala pelos Produtores de milho eram bastante limitadas.

Informações de Pesquisadores dão conta de que, concluidos os trabalhos de pesquisa com o milho piranão a nível de Unidades de pesquisa, obtidas as primeiras sementes, estas deveriam ser multiplicadas para posterior distribuição a maior nümero de Produtores com vistas a que observassem pessoalmente as características daquele material. Para tanto, contatos foram feitos com Extensionistas, a fim de que esses pudessem montar, junto a Produtores cooperadores, campos de multiplicação de sementes e tambēm para que esses campos viessem a servir, jä numa primeira etapa, como campos de demonstração. A distribuição das sementes foi feita mediante o contato com um ünico Extensionista que recebeu do Pesquisador as sementes para multiplicação e distribuição aos produtores.

Quando, posteriormente, foram feitas visitas aos campos de multiplicação, que deveriam estar sendo conduzidas pelos Extensionistas, identificou-se que tais campos se encontravam em péssimo estado vegetativo e de produção, em vista da ausência de tratos culturais adequados e indispensăveis na produção agrícola. Segundo o Pesquisador, o péssimo estado em que se achavam os campos, estava relacionado com a "desqualificação do pessoal encarregado da condução dos campos de multiplicação". Pode-se entretanto atribuir toda essa 
situação exatamente à ausència de interação maior, mais sistematizada e participativa entre todos os componentes do processo de produção agrícola (Produtores, Extensionistas e Pesquisadores) e durante todas as fases do processo de Pesquisa (Identificação do Problema, geração da tecnologia propriamente dita e transferência da tecnologia ao produtor). E é exatamente na busca de estabelecer essas interações, dentro da proposta feita pela EMBRAPA, de um modelo de Pesquisa que comece no produtor e termine no produtor com a retroalimentação do pröprio trabalho de pesquisa, que a Difusão de Tecnologia deve aprofundar a sua tarefa a fim de que o processo, como um todo, se desenvolva de forma verdadeiramente fecunda e em plenitude.

Afinal de contas, segundo a pesquisa, "o trabaIho com a CATI não funcionou". E nem poderia funcionar, dentro dos moldes em que se desenvolveram todas as suas etapas.

Por outro lado, pode-se acrescentar que, se a geração dessa tecnologia (Milho Piranão) tivesse sido desenvolvida a partir de uma reflexão mais crítica em cima do conhecimento da realidade de fato, sobre as características socio-económicas da produção do milho no Brasil, provavelmente os resultados da pesquisa seriam outros ou, pelo menos, ter-se-ia delineado a pesquisa a partir de uma metodologia mais adequada a essa prōpria realidade. Entretanto è necessário considerar-se que o milho Piranão não é uma inovação inū- 
til, mas a sua utilidade está restrita a uma categoria de produtores existentes em minoria no Brasil, pois se trata de produtores que utilizam a colheita mecânica - e a Tabela 3 ilustra bem o caráter minoritário dessa categoria de produtores - não se devendo portanto pretender sua utilização generalizada entre os produtores de milho que, em sua maioria, necessitam de um material com características diferentes.

A respeito, finalmente, dos problemas agronômicos vinculados à geração de milhos de porte baixo, pode-se ainda alocar a seguinte referência: Castro (1983) conclui que as populações braquíticas são viāveis para as condições brasileiras e que o procedimento de redução do porte de plantas pela introdução do gene br-2 em populações é uma alternativa välida.

Há que se considerar, todavia, o seguinte: Nas regiões temperadas onde se planta milho (Estados Unidos e Argentina, por exemplo) a redução do porte de planta foi, em sua maioria, feita através da seleção de plantas baixas, baseado em caracteres quantitativos (Leite, 1973). Em regióes tropicais, ênfase também tem sido dada ao uso dos caracteres quantitativos, para baixar porte de planta (CyMMIT, 1970/71). No Brasil, o uso de caracteres quantitativos (referidos acima) também tem sido adotado com muita ênfase, principalmente pelo CNPMS (Centro Nacional de Pesquisa de Milho e Sorgo-Relatōrio Técnico (1979) e empresas privadas de produção de se- 
mentes. Isto levou a que, em pouco tempo, os Ensaios Nacionais de Milho Precoce (material de porte baixo baseado em caracteres genéticos quantitativos) tivessem mais variedades e híbridos em testes do que o Ensaio Nacional de Planta Baixa, feito quase exclusivamente para os braquíticos, (CNPMS - Relatório de Ensaios Nacionais de Milho 82/83). Por outro lado, a maior parte dos novos lançamentos de híbridos comerciais das empresas privadas tém sido dos tipos baixos, sem o gene braquíticos -2 .

A base desse programa do CNPMS se assenta no fato de que os milhos de porte alto consomem bastante energia para o desenvolvimento da parte vegetativa em detrimento da produtiva, caráter que não é desejável para nenhuma categoria de produtor. Essa perspectiva tem sido profundamente estudada por Fischer (1980).

Isto permite inferir que o milho "braquítico" tem sido relegado a um plano secundārio nos programas de pesquisa, em função de outros caracteres genéticos (quantitativos), capazes de baixar o porte das plantas de milho. Por outro lado, "baixar o porte das plantas de milho" dentro de uma perspectiva que não se restrinja (como o caso do milho "piranão") à colheita mecánica parece ser o mais desejável em termos de direcionamento da pesquisa, principalmente no seu caráter metodolögico. Afinal de contas, uma tecnologia gerada que seja de interesse de um contingente superior a 0,5 do total dos 
produtores de milho do Brasil alcançará, por certo, uma probabilidade muito maior de adoção em larga escala. 
2. Expectativa de Atitudes dos Produtores em Face do Seu Envolvimento no Estudo

Dos 151 produtores que receberam o pacote com

$1 \mathrm{Kg}$ de sementes, $132(87,4 \%)$ plantaram. Considerando-se as observações feitas no ítem anterior, o tamanho reduzido da amostra de milho e o longo espaço de tempo entre o recebimento do material e época de plantio, pode-se inferir que a alta frequência de produtores que plantaram o milho pode estar relacionada com o fato de o produtor, sentindo-se valorizado por estar sendo identificado como sujeito num processo de que ele faz parte de forma indispensävel, decidiu testar o material. Esta situação pode perfeitamente justificar a atitude do produtor, de atendimento à sua convocação para parti cipação no processo. Tenderá ela, naturalmente, a se acentuar mais, à medida em que o produtor perceber que a sua palavra ou as suas observações forem definitivas para se caracterizar como verdadeiramente ütil uma tecnologia e só apōs o que, passe essa tecnologia a ser realmente recomendada em larga escala.

Tal situação, naturalmente, constituirä um profundo avanço no processo de geração e difusão de tecnologia a partir do momento em que os pesquisadores passarem a adotar como norma corrente na sua metodologia de pesquisabiolögica uma etapa até aqui não observada: Trata-se de, concluido o trabalho de pesquisa dentro das Unidades de Pesquisa e atra- 
vēs de parcelas experimentais, adotar-se mais uma repetição dos experimentos, mas agora, já com tamanhos bem maiores do que os adotados nas parcelas experimentais e diretamente na fazenda do produtor. Isto é particularmente välido a partir do fato jä observado em repetidas ocasiões e confirmada por vasto elenco de Pesquisadores de que os resultados de pesquisa alcançados nas parcelas experimentais dificilmente se repetem quando adotados pelo Produtor. E que o Sistema de Unidade Produtiva, por ser consideravelmente diferente do Sistema de Pesquisa, apresenta interações bastante diferentes daquelas observadas nas Unidades de Pesquisa. Esse fato, essencialmente empírico, contribui sobremodo para reforçar a validade da observação do conceito da interdisciplinaridade inter-sistemas, já alocado no referencial teórico, anterior. Vejamos, senão, pelo seguinte:

A medida que o pesquisador expande a sua metodologia de pesquisa e adota uma fase no trabalho de geração de tecnologia, qual seja a de estabelecer um sistema de cultivo em que sejam adotadas as recomendações remanescentes dos resultados interdisciplinares da pesquisa, ele não somente está testando experimentalmente o Sistema de Produção como reforço metodolögico ao trabalho de pesquisa, onde se podem identificar as interações entre os diversos componentes do sistema, como, ainda, de forma bastante fecunda, está tendo oportunidade de tomar um conhecimento mais profundo da própria realidade produtiva com todos os outros fatores a ela in- 
timamente vinculados, como: os fatores climáticos, os solos, os organismos e, sobretudo, os socio-econômicos. Tais fatores é que, interagindo intimamente, definem os rumos e os sistemas de produção de cada unidade produtiva. Essa questão está muito bem ilustrada na abordagem de Resende (1983), ao fazer referēncia ao tetraedro ecolögico, descrito anteriormente.

$$
\text { Por outro lado è necessärio reconhecer-se a }
$$

necessidade de que essa fase da metodologia de pesquisa seja adotada de forma sistemática em que, cada um dos componentes do processo (Pesquisadores, Produtores e Extensionistas, se for o casol sinta-se comprometido com o trabalho e possa, assim, dar a ele a atenção merecida. 
3. Reações dos Produtores em Relação às suas observações feitas em Campo Sobre o Milho Piranão

Os dados a seguir, resultantes do trabalho de pesquisa desenvolvido, são capazes de ilustrar com riqueza a percepção dos produtores sobre o milho piranão.

a) resistência a tombamento

87 Produtores, $66 \%$ dos que plantaram sementes, afirmaram a ocorrência de vento forte, durante o ciclo da cultura. $88,5 \%$ destes produtores observaram que o milho normal acamou mais que o Piranão. 4,5\% observaram que o Piranão tombou mais que o normal e $6,8 \%$ não observaram diferença no tombamento entre o Piranão e o normal.

b) variedade mais baixa

Dos 132 Produtores que plantaram a semente do Piranão, $94,5 \%$ observaram que esta variedade ficou mais bai $\times$ a que o milho normal. $0,8 \%$ não deu resposta. Chamamos aqui a atenção para o fato de que milho normal é considerado pelos melhoristas como aquele milho convencionalmente utilizado em larga escala e tradicionalmente pelos produtores. Por exemplo - Milho Cargil 111 , jä conhecido em larga escala e muito utilizado, é considerado normal em relação ao Piranão.

c) Espiga mais bai $\times a$

Dos 132 Produtores que plantaram a semente de Piranão, $92,4 \%$ perceberam que o ponto de inserção da espiga 
no colmo é mais baixo que o milho normal. $5,3 \%$ não observaram diferença. $2,3 \%$ não deram resposta.

d) incidència de caruncho

Dos 132 Produtores que plantaram as sementes do milho Piranão, $28 \%$ observaram que o Piranão está carunchado mais que o milho normal. 4,5\% observaram que o milho normal està carunchando mais que o Pi ranão. $58,5 \%$ não observaram ocorrência de caruncho e $9 \%$ dos produtores não deram resposta. Observa-se que estas questöes foram levantadas imediatamente após a colheita. Com isto, pode-se afirmar o seguinte: a ocorrência do carunchamento observada, manifestou-se ainda no campo, antes da colheita. Observe-se ainda que o milho Piranão, por ser uma variedade de grãos moles, é muito mais susceptível ao ataque dessa praga, que as variedades de grão mais duro.

Ainda se deve considerar o seguinte. de acordo com Tabela $2,3.018 .873(95,5 \%)$ de produtores de milho do Brasil estão localizados na categoria de produtores de baixa renda porque cultivam entre l e 50 ha e isto representa 12543996 $(87,5 \%)$ toneladas da produção nacional. Se considerarmos que a maioria dessa categoria de produtores produz milho para consumo na própria unidade produtiva, via de regra, na alimentação de suinos, aves e, eventualmente, animais de grande porte e que esse milho é armazenado em paiol, sujeito, portanto, ao ataque do caruncho, dificilmente ele utilizará o 
Piranão no seu sistema de produção, a menos que se venham a desenvolver outros trabalhos de melhoramento genético da planta no sentido de se obter um material com grãos mais duros e capazes, portanto, de oferecer maior resistência mecánica ao ataque dos carunchos e traças, as principais pragas do milho armazenado em paiol.

e) Vento como fator de tombamento de planta

Dos 151 produtores que receberam sementes de Piranão, $90,7 \%$ observaram que o vento é um fator importantena cultura do milho, por se constituir no principal responsável pelo tombamento e acamamento da cultura.

f) Densidade dos Grãos do Mi lho Pi ranão

Houve indicações por parte de agricultores mais atentos às características do produto obtido, segundo quais, o Piranão ẽ um mi lho mais "leve". Isto ë, com baixo peso específico em relação aos milhos normais. Embora não houvesse nümero significativo de indicações nesse sentido decidiu-se fazer menção a este fato pelo que ele pode significar em termos de rendimento físico da produção do milho piranão

g) amostras näo plantadas

Dos 151 Produtores que receberam as sementes do milho Piranão, 19 produtores $(12,9 \%)$ não plantaram, pelos seguintes motivos:

Esquecimento - 5 produtores $(26,3 \%)$ de informações. 
Tamanho reduzido da amostra - 2 produtores $(10,4 \%)$ de informações.

Falta de terra - 6 produtores ( $32 \%$ ) de informações.

Esta variável foi calculada tomando como referência as informações consideradas relevantes para serem observadas em pesquisas futuras.

Finalmente, dos 132 Produtores que plantaram experimentalmente o Piranão, $48(36 \%)$ jà decidiram rejeitá lo e não vão voltar a plantä-lo. Entre as razões apresentadas para essa decisão, o baixo rendimento do milho, o fato de o ponto de inserção da espiga no colmo ser muito resistente, o que dificulta a colheita manual, prática adotada por essa categoria de produtores, a forte incidencia de caruncho; e a falta de mercado para o Piranão, representaram $72 \%$. Ao lado desses, 74 outros produtores ( $56 \%$ ) ainda pretendem obter mais informações través de novas experiências, apōs o que tomarão uma decisão final. Ora, se numa população de produtores envolvidos no teste experimental sobre o milho Piranão, $92 \%$ es tão entre uma rejeição apōs uma primeira experiência e a obtenção de mais informações, esta é uma proporção que pode as segurar a inferência de que alēm do Piranão oferecer razões explicitadas, com segurança para sua adoção, ainda demonstra ser uma tecnologia muito pouco conhecida em detalhes pelos produtores de milho.

Por outro lado, em relação ao rendimento, há 
que se considerar o seguinte: Embora as manifestações dos produtores revelassem um baixo rendimento do milho Piranão, a identificação da pesquisa revelou, de fato, que o rendimento do Piranão foi superior ao normal. (3015 kg/ha contra 2600 Kg/ha que è o rendimento médio do Estado de São Paulo.) Provavelmente essa percepção do produtor está relacionada ao fato de que o piranão apresentar um peso específico menor que o milho normal. 
V. CONCLUSOES

Identificado o Milho Piranão e caracterizada essa variedade sintética como uma Tecnologia Moderna, estabeleceu-se a seguinte questão: se se trata de uma modernização tecnolögica, por que não vem sendo ela adotada em larga escala pelos produtores de milho de São Paulo?

$\mathrm{Na}$ verdade, entre todos os fatores que podem estar relacionados com a atitude dos produtores de milho em geral, de não adotarem essa tecnologia, pode-se considerar que, a Interdisciplinaridade - conexōes intersistemas (Pesquisador x Extensionista x Produtor) - ausente nas diversas fases do processo de Pesquisa, desenvolvido para a geração do Pi ranão, pode ser alocada como uma das que mais contribuiram para o fenômeno da sua não adoção. Senão, vejamos o seguinte:

1. Na identificação do problema, os principais critērios de seleção não se assentam no conhecimento da realidade de fato sobre a produção do milho no Brasil, o que condu- 
ziu a Pesquisa a gerar uma tecnologia para uma categoria de produtores representada por apenas $0,5 \%$ do total de produtores de milho do Brasil, responsäveis por apenas $12,5 \%$ da produção brasileira de milho.

2. Ainda a ausência dessa interdisciplinaridade determinou a geração de uma variedade de mi lho que apresentava sērios problemas agronômicos que iriam, como consequência, dificultar a sua adoção pelos produtores. Tais problemas, como a alta susceptibilidade ao ataque de carunchos e traças, o que inviabiliza o seu armazenamento em paiol, forma mais comum de armazenar milho no Brasil. Ainda grãos com baixa densidade, (peso específico) o que leva o produtor a admitir seu menor rendimento por ser mais leve que o grão de milho normal, exigindo, portanto, maior volume para produzir o mesmo peso desse milho.

3.

Finalmente, na transferència de Tecnologia, não envolvimento sistematizado dos outros componentes do processo de produção agrícola - Extensionista e Produtores, foi responsävel pela ausência de estímulos capazes de tornä-los comprometidos espontaneamente com o problema a nível de lhe dedicarem a atenção merecida.

4. 0 ponto de estrangulamento na difusão do Milho Pi ranão parece não residir apenas nos mecanismos normalmente adotados de transferência de tecnologia e nem na resistência do produtor em aceită-la, mas na sua geração, quando foram 
atendidos apenas os critérios de tecnologia útil, para faixa de agricultores de grandes äreas e colheita mecanizada.

5 . Estes resultados mostram e reforçam a validade das interações e conexões inter-sistemas (Pesquisador $x$ Extensionista $x$ Produtor), principalmente nas etapas de identificação de problemas de Pesquisa e transferēncia da tecnologia gerada e das conexões interdisciplinares - intra-sistema, principalmente na etapa da geração da tecnologia, pelas quais devem ser conduzidas as pesquisas agrícolas no Brasil de modo que os interesses e necessidades dos produtores possam ser atendidos a partir de uma integração sempre recíproca de todas as partes (Pesquisador, Extensionista, Produtor).

6. Tome-se, finalmente, para relembrar, as seguintes colocações anteriores:

- A baixa pressão de demanda por tecnologia gerando investimentos nesse setor, Mem sempre compatíneis com as reais necessidades brasileiras.

- O fato de a perspectiva interdisciplinar não estar sendo adotada em larga escala, o que aliās se justifica diante da prōpria realidade brasileira.

- A identificação de problemas de pesquisa - etapa mais importante do seu processo - tem sido atingida mediante dois enfoques: o enfoque do problema em si e o enfoque da escoIha do problema determinando muitas vezes um grau de subje- 
vidade muito grande.

- "A solução de problemas não é feita num vazio. Ela é feita num contexto que envolve não somente a perspectiva agrosilvo pastoril mas, tambēm, a perspectiva söcio-econômica.

Ao se relacionar estes aspectos às características do processo de produção de milho no Brasil em que $94 \%$ do total dos produtores de milho cultivamentre 1 e 10 ha, respondendo por $60 \%$ da produção nacional, pode-se concluir que esta é uma realidade tão expressiva que precisa ser conhecida e compreendida pelo Pesquisador.

Em suma, a proposta da EMBRAPA precisa ser compreendida em sua magnitude e alcance para que se atenda aos requisitos fundamentais e necessärios à sua operacionalização. Sem isto, corre-se o risco de gerar tecnologias por vezes inadequadas às necessidades da agricultura e dos agricultores brasileiros. 


\section{B IBLIOGRAFIA}

ALVES, E.R. e PASTORE, J. 1977. Uma Nova Abordagem Para a Pesquisa Agrícola no Brasil. Revista de Economia Rural. 15 P. $235-56$.

BRASIL. Empresa Brasileira de Pesquisa Agorpecuäria/Centro Nacional de Pesquisa de Milho e Sorgo, 1983. Programa Nacional de Pesquisa de Milho e Sorgo.

Empresa Brasileira de Pesquisa Agropecuäria/Centro $\mathrm{Na}-$ cional de Pesquisa de Milho e Sorgo, 1984. Programa de Difusão de Tecnologia.

BIASI, C.A.F.; BARBOSA NETO, A.; SILVESTRE, F.S.; ANZNATEGUI, 1.A. 1982. Métodos e Meios de Comunicação para a Extensão Rural, 2 V. Curitiba, ACARPA. P. I. Comunicação Rural.

BLUMENSCHEIN, A. 1977. "Princípios da Pesquisa no Sistema EMBRAPA". $28 p$. Mimeografado. 
BUCKLEY, W. 1971. "A Sociologia e a Moderna Teoria dos Sistemas". Ed. Cultrix Editora da Universidade de São Paulo. S. Paulo. $307 p$.

BUSCH, L. e WILLIAM B.L. 1983 Science, Agricultre, and the Politics of Research. Colorado. Westvieu Press.

BURKE, T.J. e MOLINA FILHO, J. 1982. "Processo de Decisão Individual Para Inovar: Um Modelo Alternativo". In: Revista de Economia Rural, Brasília, 20 (1): 56-76. Jan/Março.

CAStro, E. de M. de 1983. "Competição Entre Populações de MiIho Normais e Braquíticas". ESALQ - Piracicaba, Est. de São Paulo-Brasil. 155p. Tese de Doutoramento.

CIMMYT, Informe 1970/71, Sobre Mejoramiento de Maiz y Trigo. $114 p . M e ̄ x i c o$.

CONTADOR, C.R. 1975. "Tecnologia e Desenvolvimento Agrícola". R. de Janeiro IPEA/INPES. Monografia n? $17.308 p$.

1975. "Determinantes da Tecnologia Agrícola no Brasil". In: Tecnologia e Desenvolvimento Agrícola. R. de Janeiro, IPEA/INPES - Monografia n? 17 pp (131-179).

EMBRAPA/CNPMS. 1970 Relatörio Técnico Anual. 121p. Sete Lagoas, $M G$.

FISCHER, K.S. e PALMER, A.F.E. 1980. "Yeld Efficience in Tropical Maize". Trabalho preparado para apresentação no sym- 
posium "Potential Productivy of Field Crops Under Different Environments" held at |RRI September-22-26.

FRANK, A.G. 1975. "Sociologia do Desenvolvimento da Sociologia". In: Sociologia do Desenvolvimento II - Textos Bäsicos de Ciências Sociais Zahar Ed. Rio de Janeiro. pp (108182 ).

GLAJART, B. 1976. Difusão Cultural, Modernização e Subdesenvolvimento. In: Queda, 0. e Szmressänyi, T. Vida Rural e. Mudança Social. S. Paulo, Cia. Editora Nacional, p.56-65.

JAGUAR IBE, H. 1978. Modernização, Desenvolvimento Nacional e Desenvolvimento Social. Encontros com a Civilização Brasileira. 2. Civilização Brasileira.p. 41-55.

1975. "Sociedade, Mudança e Política". Ed Perspectiva, Coleção Estudos, n? 38. $225 p$.

JAPIASSU, H. 1976. Interdisciplinaridade e Patologia do Saber. Rio de Janeiro. Imago. 220 .

LEITE, D.R. 1973. "Comportamento de Milho (Zea mays, L.) Braquítico-2 Em Diferentes Densidades de Plantio" ESALQ/ USP. Pi racicaba, SP. 60p. (Tese Mestrado).

PASTORE, J. 1977. "A Criatividade na Pesquisa Agrícola" Universidade de São Paulo - Versão Condensada de "Determinantes Sociológicos da Criatividade Científica na Pesquisa Agrícola", S.Paulo, Mimeografado. $53 \mathrm{p}$. - 
1977. "Agricultura da Subsistência e Opções Tecnolögicas". São Paulo, 10p. (Mimeografado). Trabalho preparado para o "Seminärio Internacional Sobre Tecnologia Para el Pequeño Agricultor", patrocinado pelo IICA - Instituto Interamericano de Ciências Agrícolas da OEA. Assunção, Paraguai, 2-8 de maio de 1977.

PATERNIANI, E. 1973. "Orígem e Comportamento do Milho Piranão". In: Relatōrios Cientificos do Departamento de Genétican? 7 ESALQ/USP, pp (148-158) São Paulo.

J.R. ZINSLY e J.B. MIRANDA FILHO. 1977. "POPUlações Melhoradas de Milho Obitidas pelo Instituto de Genética, ESALQ/USP. Piracicaba, 11:108-114.

RESENDE, M. 1983 "O Sistema de Pequeno Agricultor: Uma Anälise Sob o Enfoque da Pesquisa, Extensão e Ensino". Universidade Federal de Viçosa, Dep. de Solos - Viçosa, MG - Brasil Agosto de $1983-72 \mathrm{pg}$ (Mimeo).

RISSI, R. de et allii. 1976. Comportamento de Híbridos e Populações de Milho (Zea mays, L.) de Porte Baixo com Duas Densidades de Plantio e em Quatro Locais. Piracicaba. USP/ ESALQ. P. 186-196. Relatörio Científico do Departamento de Genētica. $n: 7$.

SANTOS, J.P. 1983. "Levantamento de Perdas Durante o Armazenamento de Milho". EMBRAPA/CNPMS (24 pg) - Mimeo. 
SCHAUN, N.M. 1981. "Difusão de Tecnologia no Centro Nacional de Pesquisa de Milho e Sorgo". Centro Nacional de Pesquisa de Milho e Sorgo, Sete Lagoas, maio de 1981. 27p.

SCHAUN, N.M. 1977. "A Estratégia da Difusão de Tecnologia no Centro Nacional de Pesquisa de Milho e Sorgo". In: XI Reunião Brasileira de Milho e Sorgo, Piracicaba, 1976. ESALQ $1977-p .377-84$.

VALVA, F. D'A e PATERNIANI, E. 1975. "Heterose em Híbrido Intervarietal de Milho (Zea mays L.) br-2 (Braquítico-2). Piracicaba. USP/ESALQ. p.183.187. Relatörio Científico do Departamento de Genética, $N ? 9$. 


\title{
A N E X O I
}

ESCOLA SUPERIOR DE AGRICULTURA "LUIZ DE QUEIROZ"

DEPARTAMENTO DE ECONOMIA E SOCIOLOGIA RURAL

\begin{abstract}
SISTEMA DE PRODUÇÃO E ADOÇÃO DE INOVAÇÕES DA CULTURA DO MILHO DO ESTADO DE SÃO PAULO
\end{abstract}

Entrevistador:

1. Identificação:

Nome do chefe da unidade produtiva (UP):

NOME DO INFORMANTE:

Localização: Bairro: Município:

Se não proprietärio: (colocar o nome do dono da terra):

VI. Questöes sobre a cultura do milho:

1. No ano passado, que qualidade (variedade) de milho o senhor plantou?

2. Onde o senhor comprou essa(s) semente(s)? 
3. Neste ano, qual é a qualidade (variedade) de milho que o senhor vai plantar?

4. Onde o senhor pretende compra as sementes?

5. O senhor se lembra do nome ou do nümero certo dessa(s) variedade $(s)$ ?

6. (Em caso positivo) Qual(is) é (são)?

7. Neste ano, qual é o espaçamento entre as linhas que o senhor vai plantar o seu milho? centímetros.

8. Quantos pés de milho por metro de linha, em média, o senhor pretende conseguir na sua lavoura de milho? pès/metro.

9. Quantos quilos de sementes de milho o senhor gasta para plantar um alqueire de milho? quilos.

10. Qual é o tamanho da semente (peneira) que o senhor pretende plantar? Peneira(s) nūmero

11. O senhor alguma vez já ouviu falar de uma variedade de milho anão, que cresce pouco, mas produz bastante? $\mathrm{sim}$ Não

12. (Se jà ouviu falar):

a) O senhor sabe o nome dele? Qual è? 
b) Como o senhor ficou sabendo desse milho?

c) o senhor jä plantou desse milho? S i m Não

13. (Em caso de jà ter plantado desse mi lho):

a) Onde o senhor conseguiu a semente?

b) O senhor continua plantando desse milho? Si m Não

c) Por que?

14. (Em caso de conhecer, mas nunca ter plantado) Por que o senhor nunca plantou desse milho?

15. (Entregar a semente ao agricultor e anotar abaixo) Semente de PIRANÃo doada ao agricultor:

Peneira 16 HV-2 (semi-dentado)

Peneira 24 HV-2 (Semi-dentado)

Sem classificação VD-l (dentado) 

A $N E X O$
11

QUESTÕES SOBRE O MILHO

1. O Senhor acha que vale a pena (compensa) planta milho? S i m Não Depende

2. Por que?

3. O Senhor recebeu sementes do mi iho PIRANÃO?

—_ _ _ _ Não ___ Não me lembro

4. (Em caso positivo) Que semente o senhor recebeu? Peneira 16 (meio dente HV-2) Peneira 24 (meio dente HV-2) Sem classificação (VD-1)

5. 0 senhor plantou essa semente de PIRANÃo? S i m Não Não se i

6. (Em caso de näo ter plantado) Por que?

7. (Em caso de ter plantado) De modo geral, o que o senhor esachando do milho PIRANÃO? 
8. A semente de PIRANÃo que o senhor recebeu deu para plantar quantos metros de linha? metros

9. Quantas sementes de PIRANÃo o senhor plantou por metro de I inha? Sementes por metro da linha

10. Qual é a qualidade da terra em que o senhor plantou PIRA$N \widetilde{A} O ?$ Boa Média Fraca Péss i ma

11. O senhor plantou outras sementes (variedades) de milho? $\mathrm{Si} \mathrm{m}$ NNão

12. (Em caso positivo) Qual (quais) a(s) variedade(s) que o senhor plantou?

13. O PIRANÃo foi plantado a quantos metros dessas outras roças de milho? metros

14. Sistemas de produção utilizados para o milho (pacotes tecnolögicos)

\begin{tabular}{l|l|l|l|l|l}
\hline & PIRANÃO & OUTRAS VARIEDADES \\
\hline Preparação do solo & SIM & NÃO & SIM & NÃO \\
\hline Aração & & & & \\
\hline Gradeação & & & & \\
\hline
\end{tabular}


.111

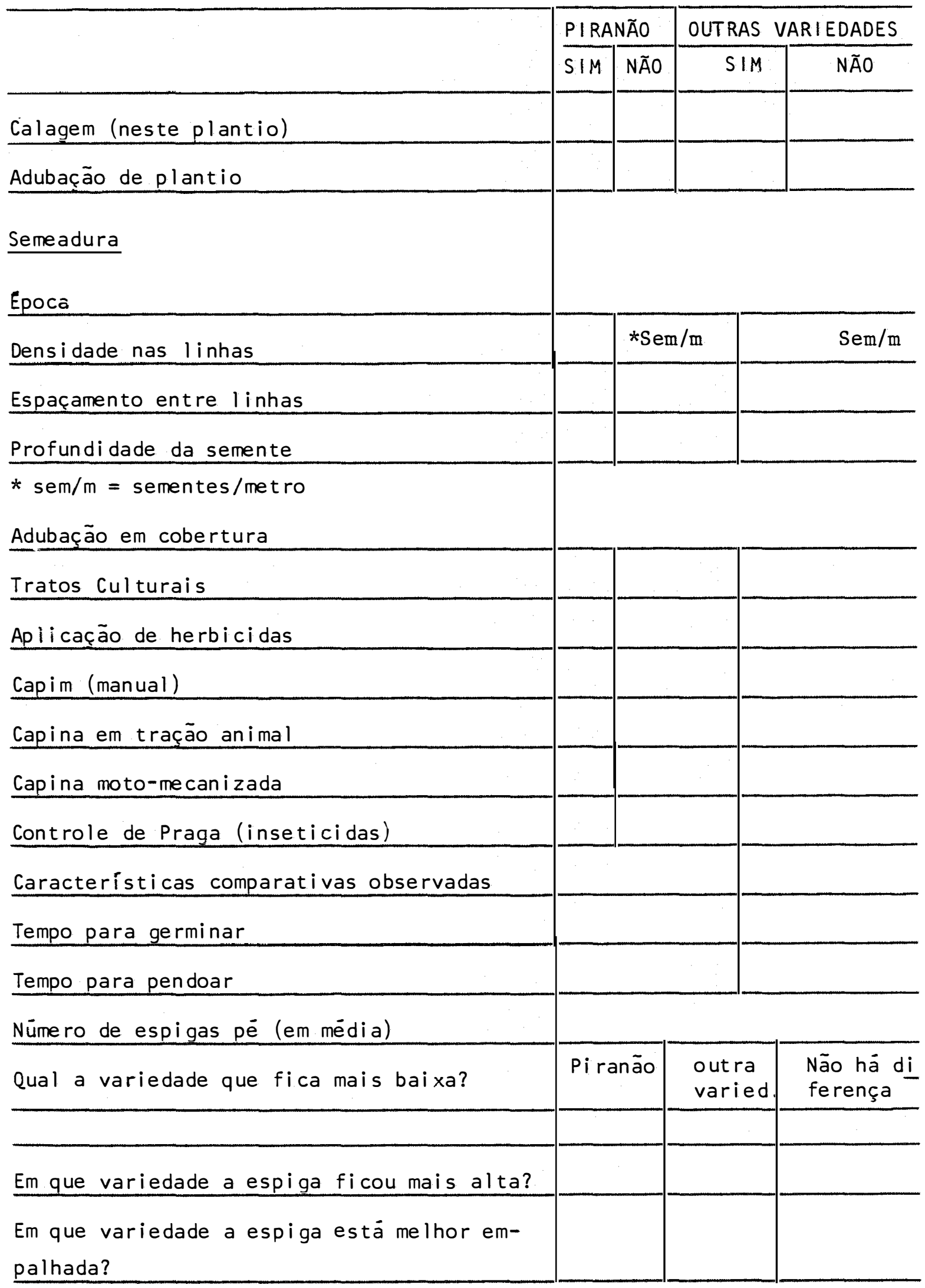




\begin{tabular}{l|l|l|l}
\hline & Pi ranão & $\begin{array}{c}\text { Outra } \\
\text { variedade }\end{array}$ & $\begin{array}{c}\text { Não hä } \\
\text { di ferença }\end{array}$ \\
\hline Qual variedade sofreu mais o acamamento? & & & \\
\hline Qual variedade teve mais pés quebrados? & & & \\
\hline $\begin{array}{l}\text { Fez lavoura (cultura) intercalar? } \\
\text { Qual (is)? }\end{array}$ & & & \\
\hline Se for uma mesma lavoura intercalar, onde \\
ela estä se dando melhor?
\end{tabular}


1. O Senhor recebeu sementes de mi lho PIRANÃO

$\mathrm{Sim}$ Não

OBS: Se não recebeu não necessita de continuar a entrevista

2. (Em caso positivo) Plantou a semente que recebeu? Sim Não

3. (Se não plantou) Por que o senhor não plantou?

OBS. (Se plantou, fazer as perguntas seguintes):

4. Quantas espigas por pé, em média, o senhor colheu de PIRANÃO? E de outro mi lho plantado?

5. Qual a variedade que ficou mais baixa?

PIRANÃO

0 outro milho plantado?

Sem di ferença

a) Quais as vantagens que o senhor acha de uma planta de mi lho mais baixa?

b) E quais as desvantagens? 
6. Em que variedade a espiga ficou mais baixa?

PIRANÃO?

0 outro mi lho plantado?

Sem di ferença

a) Quais as vantagens que o senhor acha da espiga ficar mais baixa no pë de milho?

7. Em que variedade a espiga ficou melhor empalhada?

PIRANÃO?

Outro mi lho plantado

Sem di ferença

a) O senhor acha que uma espiga deve ser bem empalhada? $\operatorname{Sim} \ldots \ldots$ Não

b) Por que?

8. Quais os problemas que o vento traz para a sua lavoura de mi lho?

a) Houve vento forte este ano aqui na roça? $\mathrm{Sim}$ Não

b) (Em caso positivo) Qual a variedade que sofreu mais o acamamento provocado pelo vento? 
PIRANĀO

0 outro mi lho plantado?

Sem di ferença

c) Quais as desvantagens de uma roça mui to acamada?

9. O senhor fez lavoura intercalada com o milho?

PIRANĀO?

Outro mi lho plantado?

a) Quais

PIRANÃO

Outro

b) (Se for uma mesma lavoura intercalar) onde ela estā se dando melhor?

PIRANĀO

Outro milho plantado

Sem diferença

10. Qual a variedade que sofreu menos a estiagem (veranico)?

PIRANÃO

Outro mi lho plantado

Sem diferença

Este ano não houve veranico

11. Qual a variedade que sofreu menos o ataque da lagarta rosca (elasmo)? Este ano não houve ataque

PIRANÃO

0 outro mi lho plantado 
Sem di ferença

12. Qual a variedade que sofreu menos o ataque da lagarta do cartucho? Este ano não houve ataque

PIRANÃO

O Outro milho plantado

Sem di ferença

13. Qual a variedade que sofreu menos o ataque da lagarta da espiga?

Este ano não houve o ataque

PIRANÃO

0 outro mi lho plantado

Sem di ferença

14. Que mês o senhor fez a colheita do mi lho? PI RANÃO

0 outro milho plantado?

15. Quantos alqueires de milho o senhor plantou? alq.

16. Quantos $\mathrm{Kg}$ de sementes o senhor plantou?

\section{PIRANĀO}

Outro milho

17. Qual a produção total que o senhor obteve? PIRANÃO sacas

0 Outro mi lho plantado sacas

18. Qual a variedade que estä carunchando mais? Este ano não houve ataque de caruncho 
PIRANÃO

0 outro mi lho plantado

Sem di ferença

19. O senhor pretende plantar novamente o mi lho PIRANÃO?

Sim Não Depende

20. Por que? (Entrevistador, insista nesta questão)

21. Quando o senhor pretende plantar o milho PIRANAO?

22. Onde o senhor pretende adquirir semente de milho PIRANÃO para plantar?

23. O senhor pretende tomar mais informações sobre o milho PIRANÃo? Sim Não

24. (Em caso positivo) Com quem o senhor pretende conseguir essas informações?

* (Entregar as informações ao agricultor) 
FACULDADE DE CIENCIAS AGRĀRIAS E VETERINÁRIAS - UNESP - JABOTICABAL DEPARTAMENTO DE ECONOMIA RURAL

PROJETO FINEP - ECONOMIA RURAL - TECNOLOGIA NA AGRICULTURA

I - Identificação:

Nome do chefe da UP:

Nome do informante:

Localização: Bairro Município:

Estrada de acesso: de a

Distância da UP à cidade mais prōxima $\mathrm{Km}$ e à sede do bairro $\mathrm{Km}$

11 - Semente recebida em julho de 1978:

III- Novas questões

1. O senhor recebeu um quilo de sementes de PIRANÃo em 1978, lembrase?

_ Sim N__ Não N Não me lembro

2. O senhor se lembra do tipo ou peneira do mi lho recebido?

3. O senhor plantou aquela semente? Sim Não

4. (Se não plantou) Por que o senhor não plantou aquela semente? 
5. (Se plantou) Na sua opinião, o que o senhor achou daquela mitho?

6. 0 que os seus amigos e vizinhos falam daquele mi lho?

7. (Se plantou) Depois que o senhor colheu aquele milho, no ano passado, o senhor obteve outras informações sobre o PIRANÁO?

Sim Não

8. (Em caso positivo) De quem o senhor obteve essas outras informa ções?

$\begin{array}{cc}\text { —_ Vizinhos } & \text { Agrônomo da Casa da Agricultura } \\ \text { Amigos } & \text { Agrônomo de Firmas de Sementes } \\ \text { P__ Parentes } & \text { Outros (Quais?) }\end{array}$

9. O senhor plantou O mi lho PIRANÃO novamente O ano passado? 80)

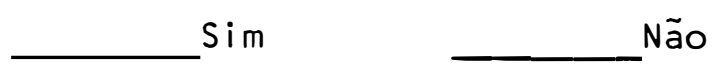

10. (Entrevistador, insista nesta questão, qualquer que seja a resposta 9)

Por que o senhor plantou (ou não plantou) novamente $\circ$ ano passado? 
11. (Em caso de ter plantado no ano passado) onde o senhor adquiriu a semente?

12. Que semente o senhor plantou?

${ }^{\text {VD-1 }}$
$16 \mathrm{HV}-2$
$24 \mathrm{HV}-2$
$\left[\_\right.$Out ra (qual?)

13. Quantos quilos de sementes o senhor plantou?

14. Quanta terra foi necessäria para plantar essa quantidade de semente (Área)? hectares

15. Quantos sacos de mi tho o senhor colheu nessa ärea? sacos

16. Qual foi sua impressão sobre a cultura do PIRANÃO ESTE ANO?

17. 0 senhor pretende plantar novamente o PIRANÃO este ano? $\operatorname{Sim}$ Não

18. (Se vai plantar novamente) onde pretende adquirir a semente?

19. O Senhor falou com mais alguēm sobre suas experiências com o mi- 
I ho PIRANÃO?

Sim

Não

Não se lembra

20. (Caso tenha falado com alguém) Com quem o senhor falou?

21. Essas pessoas, com quem o senhor falou, estão plantando o PIRA NÃO?

$$
\text { Sim }
$$

Não

22. (Para os proprietärios)

a) Hä aìguém ou outra fazenda querendo compra suas terras?

$$
\text { Sim }
$$

Não

Não sabe

b) O senhor venderia suas terras?

Sim

Não

Depende

c) Em que condições o senhor venderia suas terras? 